DEPARTMENT OF ECONOMICS

Working Paper Series

Malthus to Modernity: England's First Fertility Transition, 1760-1800

Gregory Clark

UC Davis

Neil Cummins

Queens College, CUNY

June 10, 2010

Paper \# 10-13

English fertility history is generally regarded as having been composed of two re-gimes: an era of unregulated marital fertility, from at least 1540 to 1890 , then the modern era, with regulated marital fertility, lower for higher social classes. We show there were in fact three fertility regimes in England: a Malthusian regime which lasted from at least 1500 until 1780, where fertility was substantially higher for the rich, an intermediate regime from 1780 to 1890 with fertility undifferentiated by class, and finally the modern regime. Wealthy English men produced substantially fewer children within a generation of the onset of the Industrial Revolution, over 100 years before the classic demographic transition. At the same time the fertility of the poor increased. Determining what triggered this change, however, and why it coincided with the Industrial Revolution, will require further research.

Department of Economics

One Shields Avenue

Davis, CA 95616

(530)752-0741

http://www.econ.ucdavis.edu/working_search.cfm 


\title{
Malthus to Modernity: England's First Fertility Transition, 1760-1800
}

\author{
Gregory Clark, Department of Economics, University of California, Davis \\ (gclark@,ucdavis.edu) \\ Neil Cummins, Department of Economics, Queens College, CUNY \\ (neil.cummins@qc.cuny.edu)
}

June 10, 2010

\begin{abstract}
English fertility history is generally regarded as having been composed of two regimes: an era of unregulated marital fertility, from at least 1540 to 1890 , then the modern era, with regulated marital fertility, lower for higher social classes. We show there were in fact three fertility regimes in England: a Malthusian regime which lasted from at least 1500 until 1780, where fertility was substantially higher for the rich, an intermediate regime from 1780 to 1890 with fertility undifferentiated by class, and finally the modern regime. Wealthy English men produced substantially fewer children within a generation of the onset of the Industrial Revolution, over 100 years before the classic demographic transition. At the same time the fertility of the poor increased. Determining what triggered this change, however, and why it coincided with the Industrial Revolution, will require further research.
\end{abstract}

Two events created the modern economic world: the Industrial Revolution and the Demographic Transition. The Industrial Revolution increased the growth rate of output through a stream of innovations. But as important was the Demographic Transition. Before 1800 there was some technological advance: though slow and spasmodic. But all technological advance was absorbed in raising the stock of people, not in raising living standards. Since the rich had more children than the poor, any rise in living standards induced population growth. Technological gains were consumed in maintaining ever larger populations. Only with the Demographic Transition did population gains stop absorbing much of the technological advance, allowing rapid gains in living standards.

In England, however, the Industrial Revolution dates to 1760-1800, while the Demographic Transition occurred around 1890. There is a 110 year gap between these two events. Figure 1, for example, shows the number of surviving children per woman in England by decade from the 1540s 
to the 1910s. Only in the late nineteenth century is there sign of a decline in net fertility. The Industrial Revolution itself is indeed associated with unprecedentedly fast population growth in England. These gross facts of population have led historians and demographers to focus on 1890 as the key and only break in English demographic history. They have also created a problem for theories which seek to explain modern growth through a shift from child quantity to child quality. ${ }^{1}$ The arrival of rapid and sustained technological advance clearly long preceded the Demographic Transition.

\section{FIGURE 1 HERE}

Here we show that, starting with the generation marrying in the 1760 s, there were in fact significant declines in net fertility in Industrial Revolution England, but only among wealthy men. Rich men switched from a net fertility of above 4 children, to one of 3 or less, no different than the general population. This large change in behavior does not show in the aggregate English data because at the same time the net fertility of poorer groups, the bulk of the society, increased to equal that of the rich. Thus by the time of the onset second fertility transition in 1880-1910 the net fertility of the poor was, if anything, higher than for the rich.

The limited and contradictory earlier evidence on the relationship between wealth and fertility in pre-industrial England, and the fact that marriage ages and nuptuality were seemingly similar in 1850 to their earlier levels of many decades, created a false impression that the fertility regime of the mid nineteenth century represented the entire pre-industrial period. ${ }^{2}$ In fact it was a regime of no more than 100 years. Despite many years of research into the demography of pre-industrial England we seem to have missed an earlier substantial transformation in the demographic system that accompanied the Industrial Revolution.

\footnotetext{
1 Becker, Gary, Kevin Murphy, and Robert Tamura, 1990, Galor and Weil, 2000, Galor and Moav, 2002, Hansen and Prescott, 2002, Lucas, 2002.

2 Hollingsworth showed that from 1350-1729 the net fertility of the richest of the English, ducal families, was generally below the average for England (Hollingsworth, 1965). In contrast in seventeenth century London infant death rates were higher in poorer parishes (Landers, 1993, 186-88). And studies of a parish in Lancashire (Hughes, 1986), and another in Cumbria (Scott and Duncan, 2000), correctly identified a positive relationship between both gross and net fertility and wealth in 1600-1800.
} 


\section{The Method}

We know a lot about aggregates levels of gross and net fertility in England from 1540 onwards: from parish records until 1837, then from civil birth, death and marriage registration. Parish records however, in most cases, reveal little of the wealth and income of parents. Thus demographers have accumulated little information on fertility in England as a function of income or wealth before 1850.

This means the earliest systematic evidence on differences in fertility by economic status in England comes only with a report associated with the 1911 census that correlated fertility with occupational status for marriages formed from 1851 onwards. By then wealthier groups had net fertilities no higher than those of the poor. Figure 2 shows what this 1911 report suggests. It shows net fertility for marriages of 25 or more years duration by social class, where the lower numbers are higher classes, by marriage cohort starting in 1851-60. 1851-1871 there was little or no difference in fertility by social class, with the net fertility of all these groups relatively high.

\section{FIGURE 2 HERE}

To detect the links between wealth or status and net fertility before 1840 we have to turn to another source, men's wills. There are millions of extant wills in England for the years after 1400, and a significant fraction has been transcribed or abstracted. Men only are used since before the Married Women's Property Act of 1882 married women had limited claims on marital property, and typically left wills only if widowed. Using men's wills to estimate wealth and numbers of surviving children, Clark and Gillian Hamilton show that, unlike in 1851, there was a strong positive association between wealth and net fertility 1580-1640 (Clark and Hamilton, 2006, Clark, 2007). Sometime between 1640 and 1851 there was a substantial decline in the fertility of the rich, and rise in the fertility of the poorer. Here we seek to determine when that change occurred, and also how far back before 1580 the 1580-1640 pattern extended.

To measure the connection between wealth and fertility over the long run in England we have assembled here a data sample from more than 14,000 wills from 1500 to 1914. The wills we employ are mainly sampled from three counties - Surrey (48\%), Essex (24\%), Suffolk (22\%) - but with numbers of wills also from the adjacent counties of Middlesex (1\%), Kent (1\%) and Cambridge $(1 \%)$. The geographic scope of our sample is shown in figure 3. The wills are thus sampled from a diverse area of southern England which includes rural areas, medium sized towns such as Ipswich and Colchester, and London itself in the form of Southwark. The sample before 1860 was largely determined by the availability of abstracts of the original wills. 
FIGURE 3 HERE

Wills in England before 1858 were proved in ecclesiastical courts. Our will abstracts are largely from the lower levels of these courts which included the poorest testators. But we have 1,124 wills from the highest court, the Prerogative Court of Canterbury, which dealt with the wills of the richest testators. After 1858 the wills come from the records of the Principal Probate Registry in London which preserved all probated wills in England since 1858. These PPR wills we have taken mainly from Essex and Suffolk.

In pre-industrial England a surprisingly large fraction of men left probated wills. Figure 4 shows for Suffolk the ratio of all extant probated wills of men to the estimated numbers of deaths of men aged 25 and above, 1500-1702. In some decades more than 40 percent of men dying in that decade left a surviving probated will. Thus though wills were more frequent among the wealthy, there are plenty that come from the middle and even the lower ranks of men in terms of wealth and social position in pre-industrial England. Later wills were made by a smaller fraction of men. By 1861 only 12 percent of adult men in England left a probated will. ${ }^{3}$ Wills thus cover a wide spectrum of men in pre-industrial England, but a more exclusive spectrum of the population later.

\section{FIGURE 4 HERE}

The numbers of surviving children for each testator were estimated from the wills in three ways.

(1) First there are wills where all the children were seemingly recorded. Here we counted dead children who had produced living grandchildren as "surviving" children also.

(2) Next there were wills earlier in the sixteenth century where girls tended to be omitted. Table A.2 in the appendix shows for the countryside, towns and London by period the observed average number of sons and daughters. There tends to be an equality of sons and daughters in towns, a surplus of daughters in London, and a deficit of daughters in the countryside across all periods. This may be a consequence of different mortality regimes. But in wills before 1580 we observe in both the countryside and in towns a shortage of girls compared to later. This probably stems from testators of these years not listing their married daughters, who were regarded as having received their bequests already in the form of their dowry. We corrected this omission by multiplying girls in wills in the countryside by 1.33 (1500-49),

\footnotetext{
3 Assuming that 60 percent of male deaths in 1861 were for men aged 21 or above.
} 
1.16 (1550-79), and girls in the towns by 1.53 (1500-49). This brings the ratios in these groups to their 1600-99 levels.

(3) Finally there are wills where besides the children specified, there were also indications of an unspecified number of additional children. Where we could determine in a will that the number of children was " $\geq \mathrm{n}$ " we estimated the expected number of children from the average of wills in this category (see appendix table A.2).

Estimating net fertility from wills will always tend to produce a lower bound estimate, since the errors will typically be the omission of some children. But the wills show relative net fertility levels by asset wealth, by socio-economic status, and over time.

For wills after 1841 we are also able to link many testators to individual census records from 1841 on giving the age of the testator at the writing of the will and at death. For the earlier wills we can get the age at death for a subset of more than 2,000 testators from parish records giving baptisms and marriages. ${ }^{4}$ For those testators where we do not have a direct estimate of age at death we can infer this from the observed features of the testator: their marital status, numbers of children reported in the will, numbers of grandchildren, whether one of their parents is alive, and whether they have a child aged 21 or above, whether they report a nephew or niece, whether they report siblings, and whether they describe themselves as "aged" or "ancient." The appendix reports the various methods used to fill in missing values for testators. The regression used to predict age has an $R^{2}$ of 0.52 . Thus we are able to form cohorts of male testators alternatively by birth year and marriage year.

The wealth of testators was estimated from the wills in a variety of ways. The best estimate conceptually is that where we have both details of real estate, including land areas, from the will, and the value of the "personalty" - assets other than real estate - from the court records, or after 1780 from estate tax declarations. In 3,520 out of 14,665 wills with wealth information we have such data (24 percent). The major flaws with using probate valuations as true measures of wealth other than real estate are the omissions of settled property (before 1898), and of debts and credits (Owens, Green, Bailey, and Kay, 2006, 383-384, Rubinstein 1977, 100). However for most of the testators in the range of wealth and social position that constitutes our sample, settled estates were not an issue. Where we only have the "gross" probate value, debts owed or credits due to the deceased are omitted. But for the period after 1881, Rubenstein estimates that the difference between the gross

\footnotetext{
4 See appendix table 3. For about half these cases we only get the date of first marriage, or the date of the first child born. But we can use this information to estimate a birth date for the testator from the fact that the average age at first marriage was 28 , and the average age at first birth 29.1.
} 
and net value of an estate, was on average only 5 to $15 \%$ (Owens et al 2006, 387). Where the duty value is used as an estimation of the probate value there is also an inflation of probate values for two reasons. Here the executors of the wills submitted estimates, and because of a fine for undervaluation it is believed that valuation was likely to be an overestimate of a testator's worth. Also before 1881, effects are reported as an approximation, under a certain set threshold level (e.g. under £,50, under $f_{100}$ ), which further inflates the average reported value (Owens et al. 2006, 386-387). We control for these various biases in the regressions described in the appendix which estimate total wealth.

In a second class of wills, we have information on real estate, but not land areas. Thus in 71 percent of the wills with land we have to infer the area. But we are able to approximate well the land area where it is omitted from other details of the will such as the testator's occupation and cash bequests. The $\mathrm{R}^{2}$ is 0.38 . Table A5 in the appendix details how the area of land bequeathed was estimated in the remaining 71 percent of cases.

For many wills before 1780 we do not have the probate value. This we approximate from the total value of money and goods bequeathed by the testator, using also information from other characteristics of the testator. As the appendix shows this correlates well with the net probate value. These first three groups of wills give us the assets for 88 percent of testators.

Finally there is a group of 12 percent of the wills where we have the duty value, or probate value, but no direct information on even whether or not there is real estate. These cases typically arise because a man leaves all his possessions to his wife. In these cases we have to impute the value of real estate. This we do in a two stage process. First we estimate whether there was likely to be any real estate, using a logit regression on the cases where we have both real estate data and probate values. It turns out to be very hard to know whether someone has real estate or not from the other characteristics. The pseudo $\mathrm{R}^{2}$ of this regression is very low (see table A.7). But once we attribute real estate to someone, estimating its likely value can be done more successfully (table A.8).

One test of our ability to attribute wealth elements is whether the resulting estimates correlate in the same way with other observable elements such as occupation or status. Table A.11 shows that the wills with the various kinds of attributed wealth show overall the same relationship of wealth to status as in wills with complete information.

In the course of the years 1500-1914 the real rate of return on assets in England declined significantly. The annual real purchasing power associated with a $£ 1$ of assets thus declined signifi- 
cantly over time as interest rates fell. We thus calculated an expected "bequest income stream" for each testator over time as a better way of quantifying the average value of bequests over time.

Table 1 summarizes by period the numbers of men for which we have information on assets at death and numbers of surviving children by half century death cohorts. We have over 14,000 wills coded so far, with typically more than 400 per decade for men dying between between 1700 and 1860.

\section{TABLE 1 HERE}

We also coded the occupations of the testators into 7 socio-economic status categories. These differ from the more modern socio-economic status classification because of the prevalence in status descriptions on wills even as late as the late nineteenth century of such terms as "yeoman," "husbandman" and "gentleman." But they do seem to capture socio-economic differences. Table 2 shows for men dying before 1800 by socio-economic status average assets, the percent literate (as revealed by a signed will), and average estimated age at death. Average assets and literacy were strongly correlated with the assigned socio-economic status. And there was also some correlation of the estimated age of death, with gentry testators on average dying nearly 5 years later than laborers.

\section{TABLE 2 HERE}

Table 3 shows similar correlates of socio-economic status with assets and average age at death for men dying after 1800. Again socio-economic status correlates strongly with average assets, and literacy, and is also correlated with average age at death. But there has been substantial increase in average literacy rates, average age at death, and also average assets. Now the average age of death for the gentry is 67.4, as opposed to 56.7 for those dying before 1800. Age at death also increase for laborers: from 52.1 years to 64.5. But the gentry still lived on average 3 years longer.

\section{TABLE 3 HERE}

In addition to numbers of children and wealth wills reveal the literacy of testators, and their residence. Literacy is inferred where the testator signed the will, or where they left books as possessions. Testators who signed the will with an " $x$ " are adjudged illiterate. Wills record where the person making the will was living. We have grouped these locations into London, towns including London, and the countryside. In addition, we have classified testators as living on farms where their occupation was given as farming, or where they left grain or livestock as bequests. 


\section{A First Demographic Revolution, 1780?}

Having derived measures of wealth at death, and of net fertility, for our database of testators, we can immediately show that a striking change in demographic behavior occurred for men sometime around 1800. Figure 5 shows for men ever married dying before 1830, and 1830 and later, by asset income deciles (defined over the whole sample), the numbers of surviving children identified from their wills, controlling for their location in London, town, countryside or on a farm. ${ }^{5}$ The split in terms of the decade of marriage is roughly for men marrying before 1800 and after 1800 .

For the ever married male testators in the earlier group there is a clear and very powerful association of wealth and net fertility. The men in the richest decile have an average of 4.2 surviving children, while those in the lowest decile have only 2.4 surviving children. For those marrying after 1800 this powerful wealth effect completely disappears. The numbers of surviving children per man averages 3.2 independent of their wealth decile. Thus for marriages after 1800 for rich men there was a decline in net fertility of a full child. While for the poorest testators there was a gain of nearly 0.8 children per man.

\section{FIGURE 5 HERE}

Figure 6 shows median real wealth by age for men dying before and after 1830. In both periods men seem to accumulate wealth over their lifetimes from the 20 s to the $60 \mathrm{~s}$, after which wealth stays relatively constant. Might this association be the source of the patterns shown in figure 5 . That is might the causal structure be as follows, with wealth and fertility only appearing to be causally linked?

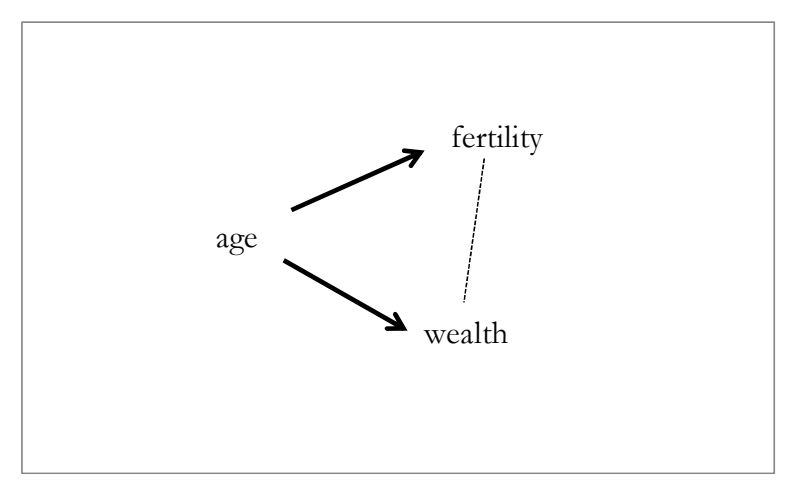

\footnotetext{
5 The will sample fails to identify some widowers, since if they have no surviving children or grandchildren, and fail to mention their deceased wife or her relatives in the will, they will be classified as single. However, the number of such omissions should be constant over time.
} 
Three considerations show age cannot be the source of the positive wealth-fertility association before 1830. First the wealth is more strongly associated with age for deaths 1830 and later, when the wealth/fertility association disappears. Second if wealth is just standing as a noisy proxy for age, then the strength of the age/wealth association has to be at least as strong as that between wealth and fertility. But wealth is a much more powerful predictor of fertility than age is a predictor of wealth. ${ }^{6}$ Lastly we can run an estimation of net fertility on wealth, controlling for the estimated age of the will maker, and the wealth effect is little diminished. It falls from a 75 percent premium in fertility for the tenth wealth decile compared to the first decile for ever married men, to a 60 percent premium once we control for age at death. But since age here is partly estimated through numbers of surviving children, and since one of the reasons for higher fertility with wealth will be lower mortality rates among the wealthier, we are definitely over-controlling for any spurious age effect here.

\section{FIGURE 6 HERE}

How abrupt was this Industrial Revolution change in fertility regimes? Figure 7 shows by twenty year probate periods the numbers of surviving children for men ever married, residing outside London, according to their asset income tercile over the whole period. Thus in each period the poorest group are those with an implied asset income below $\mathcal{f}^{5.4}$ per year (in 1630s prices), the richest are those with implied asset incomes above f15.9. A craftsman's wage income in the 1630s in England would be about $f 15$ per year, so the poorest group derive very little income from their assets, and live mainly on their labor income. The poorest group, those closest to the average person in the population in England, show a fairly constant net fertility over the entire span 15001914, but with a modest increase of about 0.4 children per year after 1800 compared to their earlier average. The richest testators show an opposing decline in net fertility. The combined effects of these movements is that the persistent net fertility advantage of the richest compared to the poorest testators, which is evident for 300 years before 1800, has disappeared by the cohort of wills probated in the 1840 s and 1850 s.

\section{FIGURE 7 HERE}

The cohort of men whose wills were probated in 1840-59, however, will potentially contain men born as early as 1740 , and as late as 1840 . Thus the periods when these men married and had

\footnotetext{
${ }^{6}$ The $\mathrm{R}^{2}$ of the relationship between wealth and fertility is several times higher than that between age and fertility.
} 
children would vary widely. To look more sharply into when this change in net fertility by wealth changed took place we group our testators into marriage cohorts of 1500-19, 1520-39, .., 1860-79. For each man a date of marriage was assigned as follows. First the date of marriage from parish or civil registration records, if that was available. Failing that an attributed date of marriage 1.1 years before the date of birth of the first child from parish or civil records. Failing that the date of marriage was taken as the estimated date of birth, using the method outlined in the appendix, plus 28 years.

A problem with these marriage cohorts is that, for reasons of record availability, we have unbalanced death cohorts. For married or widowed men outside London, for example, we have 1,243 observations for the 1630s, and 157 for the 1640s. This will lead to the marriage cohorts having an unbalanced age structure. Some will have too many older men, some too many younger men. To correct this we calculate net fertility by marriage cohort, reweighting by the inverse of the sizes of the probate cohorts who contributed observations to each marriage cohort. Figure 8 shows these results. This has the effect of smoothing the fluctuations between periods of numbers of surviving children per man.

\section{FIGURE 8 HERE}

Figure 9 shows the difference in numbers of surviving children between the top and bottom terciles by marriage cohort. This brings into sharp relief the timing of the disappearance of wealth differentiated fertility. By marriages formed 1800 and later the positive association of fertility and wealth has gone. The decline of the difference appears to proceed relatively quickly starting with the cohorts marrying in 1760. Table 4 shows the estimated difference between the fertility of the richest versus the poorest tercile by 20 year marriage cohorts for each period 1500-19 to 1860-79, controlling for testators located in London, in towns in general, and on farms. Since these are the coefficients from a negative binomial regression they show approximately the fractional amount by which net fertility of the top tercile exceeded that of the lowest tercile. Also shown are the standard errors of the estimate. After 1800 there is no longer ever any significant difference between the top and bottom terciles.

\section{FIGURE 9 HERE}

\section{TABLE 4 HERE}

The decline in the gap is a result of both the top tercile reducing its net fertility and the bottom tercile increasing its fertility. Thus at the same time as fertility as a whole began to rise in England in 
the Industrial Revolution era, the net fertility of the rich declined substantially. England experienced not one but two changes in demographic regime as modern growth commenced. The first change, which saw increased net fertility by poorer families, along with declining fertility by the rich, led to a general population boom. Only 120 years later did the rich experience a further decline in fertility to levels below those of the poor.

Another important source of differences in fertility over time in the pre-industrial world in Wrigley and Schofield (1989) is a change in the percent of women who remain unmarried. Here we have the numbers only on men, but it is interesting to ask whether the close wealth-fertility connection would be weakened if we took wealth differences in nuptuality into effect. Figure 10 shows by wealth deciles the fraction of men dying without indication that they were ever married, for men dying before 1830, and dying 1830-59.7 As noted this will be higher than the true percent never married, because men widowed without surviving children may not indicate by their wills that they were ever married.

\section{FIGURE 10 HERE}

What we see here is that for both groups of men there is a strong negative association between wealth and the changes of being never married at death. Whereas only about 12 percent of the richest men are recorded as never married, this rises to about 20 percent for the poorest men. So nuptuality rates reinforce the pattern of fertility advantage within marriage for richer men. In 183059 nuptuality patterns would also imply a modest advantage in the fertility of richer men. But we do not know if this continues for deaths post 1860.

We have examined fertility here by asset income terciles, defined across the whole sample of probates 1500-1914. Thus the line for the third tercile in figure 8 plots, for example, the mean fertility by 20 year marriage cohorts, of men with assets that generated an expected income of more than $f_{15.9}$. However, the median asset income of testators changed substantially over time. As table 1 shows for those probated in 1500-49 it was (in $£, 1630$ ), £.6, while by 1750-99 it has risen to £12.4. Partly this may be a result of the decline over time in the numbers of men leaving wills, if only the wealthier later were tending to leave wills. Figure 11 shows the share of testators by marriage cohorts in each wealth tercile from 1500 to 1880 . From 1500 to 1800 there is a steady rise

\footnotetext{
${ }^{7}$ For men dying 1860-1914 the sample over weights married men, since initially we were concerned to sample only those whose age could be obtained from the censuses of 1841 and later.
} 
in the share in the top tercile, and decline in the share in the bottom tercile. Thus the wealth of our top tercile, relative to median wealth, is much greater in 1500-19 than in 1780-99.

\section{FIGURE 11 HERE}

The long run increase in median wealth of will makers raises an interesting issue. For marriages before 1800 was net fertility determined by absolute wealth, or by relative wealth? Was it just that the relatively more successful men economically in each period were also successful in securing reproduction through securing more fertile wives, or did absolute levels of wealth confer reproductive advantage? To test the relative importance of absolute versus relative wealth we estimated the coefficients of the following regression for men residing outside London:

$$
\text { CHILDREN }=a_{0}+\sum_{i=2}^{10} a_{i} A B S D E C I L E_{i}+\sum_{j=2}^{10} b_{j} R E L D E C I L E_{j}+c_{1} D T O W N+c_{2} D F A R M
$$

where ABSDECILE are a series of 9 indicator variables for the position of the testator in the overall wealth decile for the sample of men as a whole, and RELDECILE a series of 9 indicator variables for their position in the wealth decile of the 5 decades that precede and include their probate decade. Figure 12 shows the estimated coefficients translated into percentage increases or decreases over the baseline level. They show, relative to being in the both the first absolute and relative wealth decile, what net fertility is in each of 99 combinations of other possible positions in absolute and relative wealth deciles, measured as the percentage gain or loss over this baseline. Thus the richest men, those in the tenth absolute and relative deciles, had a fertility level 78 percent higher than the baseline first decile: a product of the 52 percent advantage from their absolute position, plus a 17 percent gain from their relative position. These effect estimates suggests that absolute wealth dominates in the determination of fertility as opposed to relative wealth, though relative wealth also matters. Wealth alone, rather than relative social position, is the major determinant of fertility in England for men marrying before 1800.

FIGURE 12 HERE 


\section{Explaining the Demographic Revolution of 1780}

What drove the profound change in net fertility differences by wealth class that coincided with the Industrial Revolution? England witnessed significant social changes in the Industrial Revolution era. There were significant shifts in occupations, in residence, and in literacy. However it is a simple matter to show that none of these factors can account for the observed changes in the behavior of both the rich and the poor. The first problem with any of these as the driving force is that the social and economic changes in England in the Industrial Revolution era were gradual in comparison to the changes in demography described above between 1760 and 1800. Literacy increased, but very gradually all the way from 1560 to 1900 (Clark, 2007, 179). The percentage of people in towns, and the percentage in non-farm occupations again all increased gradually between 1500 and 1900. But the fertility revolution we observe was largely complete within 40 years.

The second problem is that when we try and explain net fertility using occupation and literacy we find that for marriages before 1800 they are all very weakly connected to fertility, once we control for wealth effects. They thus cannot explain secular changes in net fertility in any stable fashion. To see this consider the regression coefficients reported in Table 5. This is a negative binomial regression with the dependant variable the number of surviving children, and the independent variables including a dummy for each time period, for each wealth decile, for each of seven social classes, for literacy, and for town, London, and farm locations, for marriage cohorts 15001799 and 1800-1879. The coefficients again roughly indicate the percentage increase or decrease in net fertility from a given characteristic. The strong association between wealth and fertility survives even when we include measures of social and occupational status, and literacy. Controlling for wealth, literacy has no effect on net fertility, and the effects of occupations, while sometimes statistically significant, are all of modest size. The switch, for example, of the rich from farming to urban occupations explains little of the decline in fertility among that group. And the switch away from farming cannot explain the rise in net fertility amongst the poorer men.

\section{TABLE 5 HERE}

Another potential explanation of a decline in net fertility 1760-1800 among high income groups is a general decline in mortality. For the testators with observed ages we see a substantial increase between 1500 and 1914 in the average age of death. The average age of testators, reported in table 1 , rose from 52 in 1500-1549 to 66 by 1850-1914. We also observe in tables 2 and 3 that rich men had higher live expectancies than poorer men. Suppose men in pre-industrial England men wanted as many children as possible in order to maximize the chance of having at least one heir. The 
hazards of survival meant that even with relatively high net fertility rates a substantial fraction of men would die with no child to inherit. Suppose the rich consequently had "surplus" children to maximize that survivor probability. Increased chance of survival of children to age 30 or so, the typical age of children at men's death, might lead richer men, with better child survival, to have a reduced need for "surplus" children as insurance, leading to their declining net fertility.

Figure 13 shows a simple test of this possibility. It shows first for marriage cohorts before 1800 the chance of an ever married man dying without an heir as a function of their (absolute) wealth decile. $^{8}$ Even among the richest men there was a 12 percent of dying without an heir. Their chances of dying childless were, however, significantly lower than for the poorest men. However, for the richest men marrying 1800-1879 the chances of dying childless rose significantly. For the top decile it became 21 percent, nearly twice as high as before. It is not possible to interpret the onset of declining net fertility in the rich as coming from any better ability to target completed family sizes. ${ }^{?}$

\section{FIGURE 13 HERE}

\section{Further Work}

A powerful idea among economists has been that a greater role of human capital in generating income lead to the modern fertility decline. ${ }^{10}$ The key idea in this literature is that in the modern world there is a higher cost in terms of the income and consumption of each child from larger family sizes. Is there any sign that after 1760 the costs of having children increased for the rich, but decreased for the poor? This seems unlikely. For a start, the wealthy in pre-industrial England whose income depended largely on the possession of land or houses always had a strong incentive to limit fertility if they wanted to maintain the living standards of their children. The family assets would get divided up among the children, so that with more than two children average expected assets per child would decline. ${ }^{11}$ In a world post 1800 where education was the key to income, since

\footnotetext{
8 Controlling for location.

${ }^{9}$ Clark and Cummins, 2009, gives further evidence against this possibility, through an examination of the fertility patterns of men in different mortality environments in pre-industrial England. The countryside was so much safer than London that if reduced mortality risks were to lead to declining fertility, it should already have happened in the most rural locations even before 1800 .

10 See, for example, Lucas, 2002, Becker, Murphy and Tamura, 1990.

11 Spouses would also bring assets to marriages, so that a child with half the assets of a parent would on average end up in a family with assets equal to that of the parental family.
} 
there was a maximum cost of education, the richest could afford to have as many children as they wanted, and still give them all the maximum possible amount of education.

One test of this possibility, though it depends on obtaining more data than we have at present, is to look at the connection between the wealth of fathers and sons in our will sample. Fathers can be conceived of influencing the wealth of sons through two channels. The first is through mechanisms such as genes, culture, and social position that are independent of the number of children. The expected wealth of the child through this channel will be some function of the wealth of the father, $\mathrm{W}_{\mathrm{f}}$. The second mechanism is through the transfer of wealth and resources such as training time and formal education from father to son. The influence here will depend on the numbers of children sharing the resources of the father. The wealth of children will be a function of $\mathrm{W}_{\mathrm{f}} / \mathrm{N}$, where $\mathrm{N}$ is the number of children (assuming daughters inherit as much as sons). The relative magnitude of effects through this channel compared with the unlimited transfer will dictate how strong the quality-quantity tradeoff is.

The basic estimating equation is thus

$$
\ln \left(W_{s}\right)=b_{0}+b_{1} \ln \left(W_{f}\right)+b_{2} \ln \left(\frac{W_{f}}{N}\right)
$$

With this formulation, the estimated coefficient $-\mathrm{b}_{2}$ is the elasticity of son's asset income as a function of the father's number of surviving children. The coefficient $b_{1}$ shows the direct link between fathers' and sons' wealth, independent of the size of the fathers' family. The sum of the coefficients, $b_{1}+b_{2}$, is the total elasticity of sons' wealth with respect to fathers. If family size fell among the rich, and rose among the poorer, after 1760 as a result of changes in the strength of the tradeoff between quantity and quality then we would expect the following values for the estimated coefficient $\mathrm{b}_{2}$ :

\begin{tabular}{|c|c|c|}
\hline & Rich & Poor \\
\hline $1500-1780$ & $<\mathrm{b}$ & $>\mathrm{b}$ \\
\hline $1780-1914$ & $\mathrm{~b}$ & $=\mathrm{b}$ \\
\hline
\end{tabular}

That is, compared to the value of $b_{2}$ for the rich after 1780 , the value for the rich before should have been lower, and for the poor higher. After 1780 since the rich and poor had the same family size then the quality/quantity tradeoff should have been the same for them. We are at work on 
accumulating sufficient number of father son pairs of the various types and periods to conduct this test.

The surprisingly sudden change in the pattern of fertility with wealth makes it hard to explain through economic variables which were all changing only slowly in England in these years, even though it is the period of the Industrial Revolution. This suggests an alternative explanation in the form of some social or ideological movement. One possibility, for example, is that the decline in fertility among the rich was a reaction among the economically successful to the widespread publicity afforded Thomas Malthus's Essay on a Principle of Population, first published 1798, but re-issued in five revised editions until the author's death in 1834. We would expect, however, such a social or intellectual movement to be associated with occupations or professions more than with incomes. Such an explanation would imply conscious control of fertility by richer men in marriages formed 1780 and later. This control could take the form of marrying older women. For the men that we successfully linked to parish records we do note that in general testators marry women 2.5 years younger than in the general population in the seventeenth century, but 0.9 years older by 1800-37 (table A.4). This would account for considerable fertility differences. But to investigate this systematically, and to show that it was a change of behavior specifically among richer testators, we need to link many more testators to parish records, which we are in the process of doing. Also from records of baptisms and births we can determine whether birth intervals increased for the rich after 1780 , or whether there is sign of stopping behaviors.

A further feature of our data that shows in figures 8 and 9 is that the gap between the fertility of richer and poorer men is even wider for sixteenth century marriages than it is for the years 16001760. This may be an artifact since we have much less data for the years before 1540 , especially for the richest tercile. Consequently we have not tried here to explain this. But there are sources that will allow us to extend the wills sample in greater depth back to marriages even of the 1430s which would allow an investigation of even late medieval fertility, and of whether there were even earlier changes in the fertility of the rich than we have identified here.

Another area of potential further research is in the parallels between the change in fertility regime in England in the late eighteenth century, and the well known regime change in France. Aggregate fertility decline in France preceded England by over a century. This is surprising because if the fertility transition was a result of changing economic conditions, we would expect England, the crucible of the Industrial Revolution, to be first. One of us has collected similar wealth and fertility samples for four rural French villages, for deaths 1810-70, corresponding to fertility circa 1780-1850 (Cummins 2009). Before the fertility decline, as in England, there is a positive relationship between 
wealth and net fertility. However, as the fertility transition begins in France, in the 1780s, the relationship reverses even more rapidly than in England. The richest villagers were the pioneers of family limitation. In rural France, where fertility was declining, the rich by the end of the period 1810-70 display fertility 38\% lower than that of the poor (Cummins 2009, 15). Why did France experience this accelerated change in the relationship between wealth and fertility?

\section{Conclusion}

While there is still much work to be done on the precise mechanisms and causes, we demonstrate above that pre-industrial fertility patterns did not survive unchanged in England until marriages of the 1870 s as has been conventionally believed. Instead there was an important and rapid change in fertility patterns by wealth for marriages formed 1760-1800. Up until then the richest English men were producing more than 4 surviving children at a time when men in general produced only 2.5 surviving children. Within a generation the fertility of the rich fell to be no greater than, and perhaps less, that of the general population. A Demographic Revolution thus accompanied the Industrial Revolution. Now united temporally, the two events may also be more plausibly linked causally.

\section{Appendix - imputing missing values}

In forming the data base of fertility, estimated wealth at death, estimated dates of birth, and estimated dates of first marriage, we had to assign values in a number of cases where data was missing: birth, and marriage dates, area of land holding, numbers of children (where only a partial count was given).

\section{Replacing missing girls pre $\mathbf{1 5 8 0}$}

In the earliest wills, those before 1580, the ratio of sons to daughters is far above 1 , so some daughters are clearly missing. This is probably because married girls got their share of the bequest at the time of marriage, and so are not mentioned in the wills. To inflate the reported family size to an estimate of the correct size the number of daughters reported was multiplied in these early years by an inflation factor. Numbers of girls were multiplied by adjustment factors that make the boy/girl ratio the same as 1600-99 for the same type of location: countryside, town or London. 


\section{TABLE A.1 HERE}

\section{Imputing numbers of children}

In some cases we only have partial information on the numbers of surviving children a testator has, such as that he has at least two children. We impute the likely numbers of children in the way shown in table 2. Since average family sizes were greater in the countryside than in towns, and greater in towns than in London, we did the imputation separately for each location. Since average family sizes also changed over time we estimated these numbers for each of three periods: 15801799, 1800-59, and 1859-1914. Column 3, for example, shows the average numbers of children in families with at least 1 child for each location and time period. The cells were left blank if there were fewer than 4 families observed in that cell. Where we know, for example, just that a testator had at least 1 child in the years 1500-1799, then he was imputed 3.63 children if he lived in the countryside. For London where we had to impute child numbers and the cell in the table was blank, we moved to the cell above for the imputation.

\section{TABLE A.2 HERE}

\section{Imputing testators birth dates}

As table A.3 shows for a large number of testators we are able to assign them a birth date, marriage date, or age at first child by linking them to the censuses of 1841 and later, or by linking them to parish registers of baptisms and marriages. This linkage is more successful for men with unusual names, or those who were married and had children (since then we have multiple checks on whether they are properly equated with the person in the parish records).

\section{TABLE A.3 HERE}

With these direct linkages of men to birth, marriage and first child dates we impute birth dates for all the men in our sample without direct information through the following regression

$$
\begin{aligned}
& \text { AGE AT WILL }=52.40+7.99 \mathrm{DAGED}+0.868 \mathrm{~N}+7.56 \mathrm{DCHILD}>21-9.52 \mathrm{DCHILD}<21+ \\
& \text { 4.88DGRANDCHILD - 3.94DSINGLE + 5.75DWIDOWER }-7.15 \mathrm{DPARENT}+ \\
& \begin{array}{l}
\text { 4.56DNEPH }-2.47 \mathrm{DSIB}-3.08 \mathrm{DLON}+6.38 \mathrm{DLON} 1800-1.55 \mathrm{DTOWN}+1.15 \mathrm{DFARM}- \\
3.34 \mathrm{D} 1500-0.35 \mathrm{D} 1650+1.42 \mathrm{D} 1750+1.27 \mathrm{D} 1800+4.56 \mathrm{D} 1830 \\
\mathrm{n}=1,962, \mathrm{R}^{2}=0.52
\end{array}
\end{aligned}
$$


DAGED = indicator testator noting he is "aged", "ancient" or equivalent

$\mathrm{N}=$ number of surviving children

DCHILD $>21=$ indicator for at least one child known to be more than 21

DCHILD $<21=$ indicator for at least one child known to be less than 21

DGRANDCHILD = indicator for at least one known grandchild

DSINGLE = indicator for testator never married

DWIDOWER $=$ indicator for testator widower

DPARENT $=$ indicator for at least one parent known to be alive

$\mathrm{DNEPH}=$ indicator for a living niece or nephew

DSIB $=$ indicator for a living sibling

DLON $=$ indicator for residence in London

DLON1800 = indicator for residence in London 1800 or later

DTOWN = indicator for testator resident in a town (including London)

DFARM = indicator for a testator living on a farm

D1500, D1650, D1750, D1800, D1830 = indicators for years of death 1500-1649, 1650-1699, 1750 -

1799, 1800-1829, 1830-1914

The fit of this expression, as measured by the $\mathrm{R}^{2}$, is good. From this expression we estimate the date of birth of all testators without direct information on this as the will date - the estimated age at the will. For some wills we only have a probate date. To estimate the age at the will in this case we use the average gap between the dates of wills and the dates of probate, 2 years, to derive an estimate of age at the will.

The parish records also allow us to calculate the average age at first marriage for men and their wives. This data is summarized by period in table A.4. The average age here is calculated for the first marriage of testators, and for marriages for women not known to be have been married before. For testators the age at first marriage is remarkably stable over time, at around 28 years. For comparison the average age of men in bachelor/spinster marriages from Wrigley, Davies, Oppen and Schofield (1997) (hereafter WDOS) is also shown. Famously WDOS show a decline in the age of marriage for men from 27.5 years in the $17^{\text {th }}$ century to 25.1 years in 1800-37. For most of this period the testators thus tend to be older than the grooms in the reconstituted parishes. Similarly the wives' ages are shown. Wives averaged only 24 at marriage, with again no trend over time. Again there is no sign of the downwards trend observed in WDOS. Finally the gap between mens' and womens' ages at marriages for the testators is 3.8 years, compared to 1.6 years for the population as a whole. 
TABLE A.4 HERE

The stability of the marriage age for male testators means that we can assign marriage dates of the date of birth plus 28 years throughout the sample where a marriage date is not directly observed.

\section{Imputing Land Areas}

In 60 percent of the cases where land was bequeathed, the area of the land was not indicated. To infer the area for these wills we estimated for cases where area was given, that area as a function of other features of the will. In all cases we used the number of houses bequeathed, the number of parishes the land was described as lying in, an indicator for the literacy of the testator, an indicator for whether the testator lived in a town, an indicator of whether the person engaged in farming, and indicators for each occupational group. Where the probate value was given this was also included, where not the total of goods and cash bequeathed. The functional form that best fit the observed cases was chosen by experiment. Thus the estimated expression was

$$
\begin{aligned}
& \log (\text { AREA })=a+b_{0} \text { DPCC }+b_{1} \text { SQRTHOUSE }+b_{2} \text { LPAR }+b_{3} \text { SQRTPROBATE }+ \\
& b_{4} \text { SQRTCASHGDS }+b_{5} \text { DLIT }+b_{6} \text { DLITUNKNOWN }+b_{7} \text { DTOWN }+b_{8} \text { FARM }+ \\
& b_{9} D 1700+b_{10} D 1800+\sum_{i} c_{i} \text { OCCUP }_{i}+e
\end{aligned}
$$

where SQRTHOUSE was the square root of the number of houses left, LPAR the logarithm of the number of parishes the land was in, SQRTPROBATE the square root of the net probate or duty value of the estate (real absolute values), 0 otherwise, SQRTCASHGDS the square root of the absolute value of cash and stock bequeathed (real values) (when probate or duty values not available), 0 otherwise, DLIT an indicator for a literate testator, DLITUNKNOWN an indicator for someone whose literacy is unknown, DTOWN an indicator for a town dweller, DFARMER an indicator for someone engaged in farming, D1700 an indicator for a probate year of 1700-99, D1800 an indicator for a probate year of 1800 or later, and OCCUP indicators for the six occupational groups defined above. DFARM was set to one if the testator left farm animals or grain in the will, or left farm implements.

CASHGDS was constructed as was constructed using the actual cash bequests in the will normalized by the average price level in each decade (with the 1630s as the base). To this was added the value of the stock left calculated using a standard set of values normalized to the 1630s: horses $f^{5}$, 
cattle $\AA^{4}$, sheep $\AA_{0.5}$, pigs $\AA^{2}$, wheat (bu.) $\AA_{0.21}$, barley/malt (bu.) $\AA_{0} 0.10$, oats (bu.) $£_{0} 0.07$, peas/beans (bu.) $\AA^{0.12}$, silver spoons $\ell^{0.375}$, gold rings $£_{1} 1$.

The fitted coefficients for this regression are shown in table A3. The $\mathrm{R}^{2}$ of these regressions was 0.38 , suggesting that we can explain nearly forty percent of the variance of land areas with these controls. The median land area where the area was greater than 0 was 7 acres, the median estimated area was 9.1 acres (the means were respectively 27.8 and 31.2 acres).

\section{TABLE A.5 HERE}

\section{Imputing Probate Values}

Before 1858 there are many cases where we have no direct information on the value of the personalty from the probate or the duty declaration. Instead we have the gifts of cash and goods in the will, as well as real estate values and other characteristics of the testator. To get all valuations on a uniform basis we estimate real probate values from real cash and goods values, and the other characteristics of testators. The estimating equation is

$$
\begin{aligned}
& \text { PROBATE }=a+b_{0} \text { DPCC }+b_{1} \text { DNONCUP }+b_{2} \text { CASHGDS }+b_{3} \text { REALEST }+ \\
& b_{4} D L I T+b_{5} \text { DLITUNKNOWN }+b_{6} D L O N+b_{7} \text { DTOWN }+b_{8} \text { FARM }+ \\
& b_{9} D 1500+b_{10} D 1700+b_{11} D 1800+b_{12} D 1860+\sum_{i} c_{i} \text { OCCUP } P_{i}+e
\end{aligned}
$$

Table A.6 shows the estimated coefficients for this regression, where the median regression is used. The Pseudo- $\mathrm{R}^{2}$ is 0.31 . The main variable which matters in the regression is CASHGDS, the real value of goods and cash bequeathed. A regression with only this variable has a Pseudo- $\mathrm{R}^{2}$ of 0.29. If OLS is used on the whole expression the $\mathrm{R}^{2}$ is an even more impressive 0.62. However, the problem with the OLS estimation is that the range of probate values in the sample is very skewed, ranging from $£^{0}$ to $£ 78,482$ with a median of only $£ 133$. The OLS fit is thus dominated by fitting the high probate values, while we are much more concerned about correctly fitting probate values to people at the bottom end of the distribution. The median estimator which relies on minimizing absolute rather than squared deviations is thus more appropriate. An alternative technique which is used above is to take the log of the dependent variable (land area or real estate value), but here we run into problems of both 0 and negative values for CASHGDS and PROBATE.

TABLE A.6 HERE 


\section{Imputing All Real Estate}

Where the land area can be estimated, and the number and kind of houses is also approximated, then the value of real estate is the number of each type of asset (houses in the country, houses in town, houses in London, mansions (country), and other buildings or physical assets (mills, boats), and land multiplied by an appropriate price index.

In some cases, however, we have no information on real estate from the will. All that may be know is the probated value of the personalty of the estate, or the duty band for the purposes of estate taxation. This would be, for example, because all assets, unspecified, were left to the wife. Here we infer real estate values in a two step procedure. First we estimate whether there was any real estate through a logit regression. Using a sample of cases where we know the presence or absence of real estate in the estate we estimate the likelihood that there was real estate as a function of other observable characteristics: what type of will was it (PCC is an indicator for a Prorogative Court of Canterbury will, PNONCUP an indicator for a nuncupative (spoken) will), what period was it, what was the probate value, was the testator literate or of unknown literacy, where did they dwell, and what was their occupation. These estimates are shown in table A.6. The dependent variable is 1 if there is no real estate, 0 otherwise. Unfortunately the pseudo $\mathrm{R}^{2}$ of this regression is only 0.08 . It is not possible to estimate well from the observed characteristics of testators whether or not they owned real estate.

\section{TABLE A.7 HERE}

For cases where we assign real estate we estimate its value from the coefficients given in table A.8, which estimates the log of property value from observed characteristics of testators when it is known property was bequeathed. The $\mathrm{R}^{2}$ of this estimation is much better at 0.31 .

\section{TABLE A.8 HERE}

However, the overwhelming majority of cases in which we have to infer whether there was any real estate come after 1780, when the probate documents begin to list an estimated probate value. As the second column of table A.9 shows, in these years real estate was declining as a component of the total value of assets bequeathed, looking at all wills with complete information. By 1860-1915 real estate was only 21 percent of the value of all bequests. Thus even those wills where we have only the personalty values directly should give a reasonable guide to the total value of the bequest. The third column shows what fraction of wills where we know of any real estate had some real estate of any kind. In all cases, in a majority of wills, there is no real estate bequeathed. The last column of table A.9 shows for those wills where there is land what the share of the land value is to 
the total value of the bequest. Again, while our imputation is imperfect here also, land is always a third or less on average of the bequest in such cases, so the extra error from this imputation is not too great.

\section{TABLE A.9 HERE}

Table A.10 summarizes our data by the degree of imputation of wealth components that is required. The data is ranged in a rough scale of quality. The best wills are those where we have both the probate values and details of the real estate. The poorest imputations are for wills where we have to estimate whether or not there is real estate, and then also the value of the real estate.

\section{TABLE A.10 HERE}

To test how well we are doing in imputing wealth where we have incomplete information, table A.11 shows the median wealth of testators compared to their status/occupational class for each type of wealth imputation. For the first four imputations of wealth the rankings of the different status/occupational classes are very similar in terms of median estimated wealth. Only for the last group, where we infer real estate from probate values and other indicators, do the wealth rankings seem less consistent. 


\section{References}

\section{Primary Sources of Wills}

Essex Record Office, Chelmsford - Archdeaconry and Consistory Court Wills, 1500-1857

London Metropolitan Archive - Archdeaconry and Consistory Court Wills, 1600-1857

Public Record Office, Kew - Prerogative Court of Canterbury Wills, 1500-1857

Suffolk Record Office - Archdeaconry Court Wills, 1500-1857

Probate Dept of The Principal Registry Family Division - all wills 1858-1914.

\section{Published Transcripts of Wills}

Allen, Marion E. 1989. Wills of the Archdeaconry of Suffolk, 1620-24. Woodbridge, Suffolk: Boydell Press for the Suffolk Records Society, Volume 31.

Allen, Marion E. 1995. Wills of the Archdeaconry of Suffolk, 1625-26. Woodbridge, Suffolk: Boydell Press for the Suffolk Records Society, Volume 37.

Allen, Marion E. and Nesta Evans. 1986a. Wills from the Archdeaconry of Suffolk, 1629-36. Boston : New England Historic Genealogical Society.

Allen, Marion E. and Nesta Evans. 1986b. Wills from the Archdeaconry of Suffolk, 1637-40. Boston : New England Historic Genealogical Society.

Emmison, F. G. 1978. Elizabeth Life: Wills of Essex Gentry and Merchants, proved in the Prerogative Court of Canterbury. Chelmsford, Essex: Essex Record Society Publication, \# 71.

Emmison, F. G. 1990-2004. Essex Wills, 1558-1603. Volumes 2-11. Chelmsford: Essex Record Office.

Evans, Nesta. 1987. The Wills of the Archdeaconry of Sudbury, 1630-35. Suffolk Records Society, Vol. 29. Woodbridge, Suffolk: The Boydell Press.

Evans, Nesta. 1993. The Wills of the Archdeaconry of Sudbury, 1636-38. Suffolk Records Society, Vol. 35. Woodbridge, Suffolk: The Boydell Press.

http://linux02.lib.cam.ac.uk/earlscolne/probate/index.htm Transcripts of wills of testators from Earls Colne, Essex, 1490-1857.

Webb, Cliff. 1996-2004 Surrey Will Abstracts, Vols. 1-41. West Surrey Family History Society.

\section{Other Sources}

Becker, Gary, Kevin Murphy, and Robert Tamura. 1990. "Human Capital, Fertility and Economic Growth.” Journal of Political Economy, 98: S12-37.

Clark, Gregory. 2005a "The Condition of the Working-Class in England, 1209-2004" Journal of Political Economy, 113(6) (December, 2005): 1307-1340.

Clark, Gregory. 2005b "Human Capital, Fertility and the Industrial Revolution," Journal of the European Economic Association, 3 (2-3): 505-515.

Clark, Gregory. 2007. A Farewell to Alms: A Brief Economic History of the World. Princeton University Press.

Clark, Gregory. 2010. “The Macroeconomic Aggregates for England, 1209-2008." Research in Economic History, 27, 51-140. 
Clark, Gregory and Neil Cummins. 2009. "Urbanization, Mortality and Fertility in Malthusian England." American Economic Review, 99(2) (May): 242-7.

Clark, Gregory, Joseph Cummins, and Brock Smith. 2010 "How rich was pre-industrial England?"

Working Paper, University of California, Davis.

Clark, Gregory and Gillian Hamilton. 2006 "Survival of the Richest. The Malthusian Mechanism in Pre-Industrial England.” Journal of Economic History, 66(3) (September): 707-36.

Cummins, Neil J. A Comparative Analysis of the Relationship between Wealth and Fertility during the Demographic Transition: England and France. PHD Thesis London School of Economics, 2009.

Galor, Oded and David N. Weil. 1996. "The Gender Gap, Fertility and Growth." American Economic Review, 86: 374-387.

Galor, Oded and David N. Weil. 2000. "Population, Technology and Growth: From Malthusian Stagnation to the Demographic Transition and Beyond." American Economic Review, 90: 806-828.

Galor, Oded and Omer Moav. 2002. "Natural Selection and the Origin of Economic Growth." Quarterly Journal of Economics, 117: 1133-1192.

Great Britain Historical GIS. 2009. "English Administrative Counties, 1910 and English Urban/Rural Areas 1910.” http://borders.edina.ac.uk/ukborders/action/restricted/textgeosearch.

General Registrar's Office. 1923. Fertility of Marriage, Part 2 Census of England and Wales, 1911. Vol. XIII, London: HMSO.

Hansen, G. and Prescott, Edward C. 2002. "Malthus to Solow." American Economic Review,92(4): 1205-1217.

Hollingsworth, T. H. 1965. The Demography of the British Peerage. Supplement to Population Studies, v. 18, no. 2. London: Population Investigation Committee, London School of Economics.

Hughes, Austin 1. 1986. "Reproductive Success and Occupational Class in Eighteenth Century Lancashire, England." Social Biology, 33: 109-115.

Landers, John. 1993. Death and the Metropolis: Studies in the Demographic History of London, 1670-1830. Cambridge: Cambridge University Press.

Lucas, Robert E. 2002. "The Industrial Revolution: Past and Future" in Lectures on Economic Growth. Cambridge, Mass.: Harvard University Press.

Garret, Eilidh et al. Changing Family Size in England and Wales: Place, Class and Dempgraphy, 1891-1911. Cambridge: Cambridge University Press.

Jones, Larry E. and Michèle Tertilt. 2006. "An Economic History of the Relationship Between Occupation and Fertility - U.S. 1826-1960.” Working Paper, Stanford University.

Owens, A. Green, D.R., Bailey, C., and Kay, A.C. 2006. "A measure of worth: probate valuations, personal wealth and indebtedness in England, 1810-40" Historical Research 79 (205): 383-403.

Rubenstein, W.D. 1977. "Wealth, Elites and the Class Structure of Modern Britain." Past and Present

Scott, Susan and C. J. Duncan. 2000. "Interacting effects of nutrition and social class differentials on fertility and infant mortality in a pre-industrial population." Population Studies, 54(1): 71-87.

Titelbaum, Michael S. 1984. The British Fertility Decline: Demographic Transition in the Crucible of the Industrial Revolution. Princeton: Princeton University Press.

Van Bavel, Jan. 2002. "Detecting Stopping and Spacing Behavior in Historical Fertility Transitions: A Critical Review of Methods." Working Paper, Department of Sociology, KU Leuven.

Wrigley, E.A 1969. Population and History.

Wrigley, E.A, and Schofield, R.S. 1981. The Population History of England 1541-1871. Cambridge: Cambridge University Press.

Wrigley, E. A., R.S. Davies, J.E. Oeppen, and Roger Schofield. 1997. English Population History from Family Reconstitution, 1580-1837. Cambridge: Cambridge University Press. 
Figure 1: Net fertility trends in England, 1540s-1910s

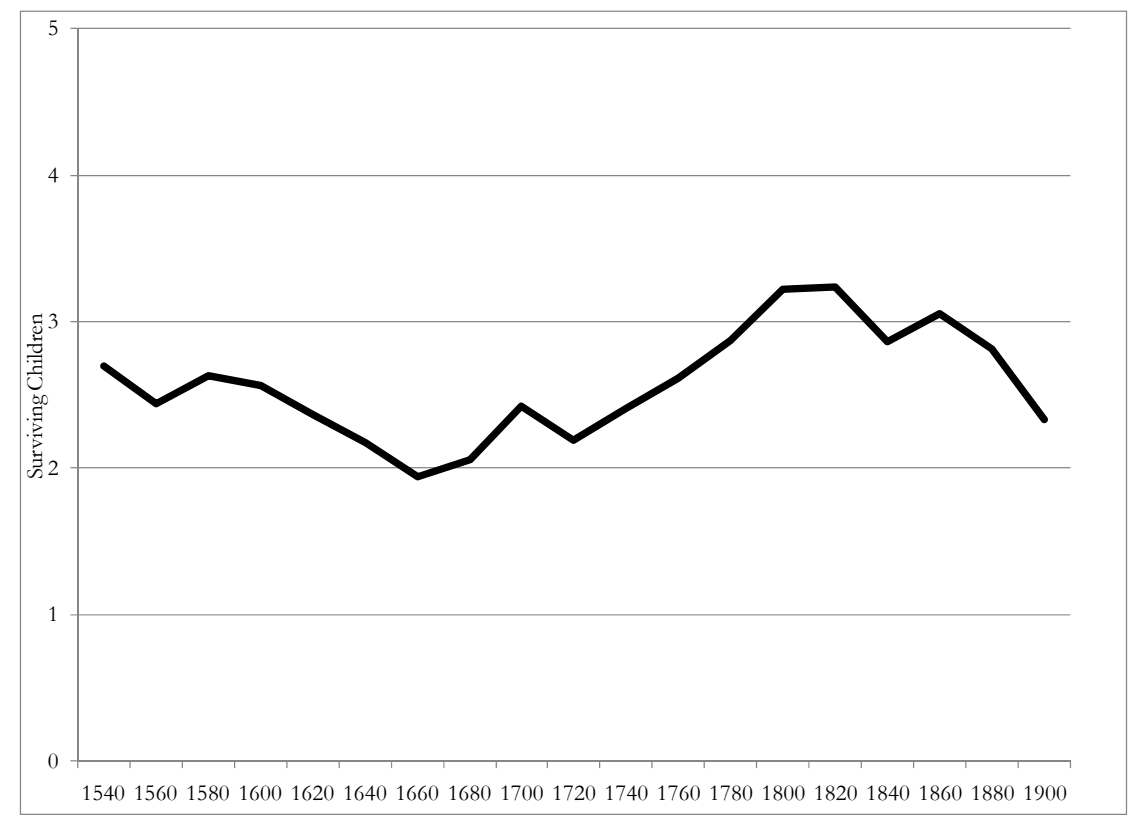

Source: Wrigley and Schofield, 1981, 528-9, table A3, Wrigley, 1969, 196, Table 5.16.

Figure 2: Net Fertility by Social Class, Married Men, Marriages 1851-86

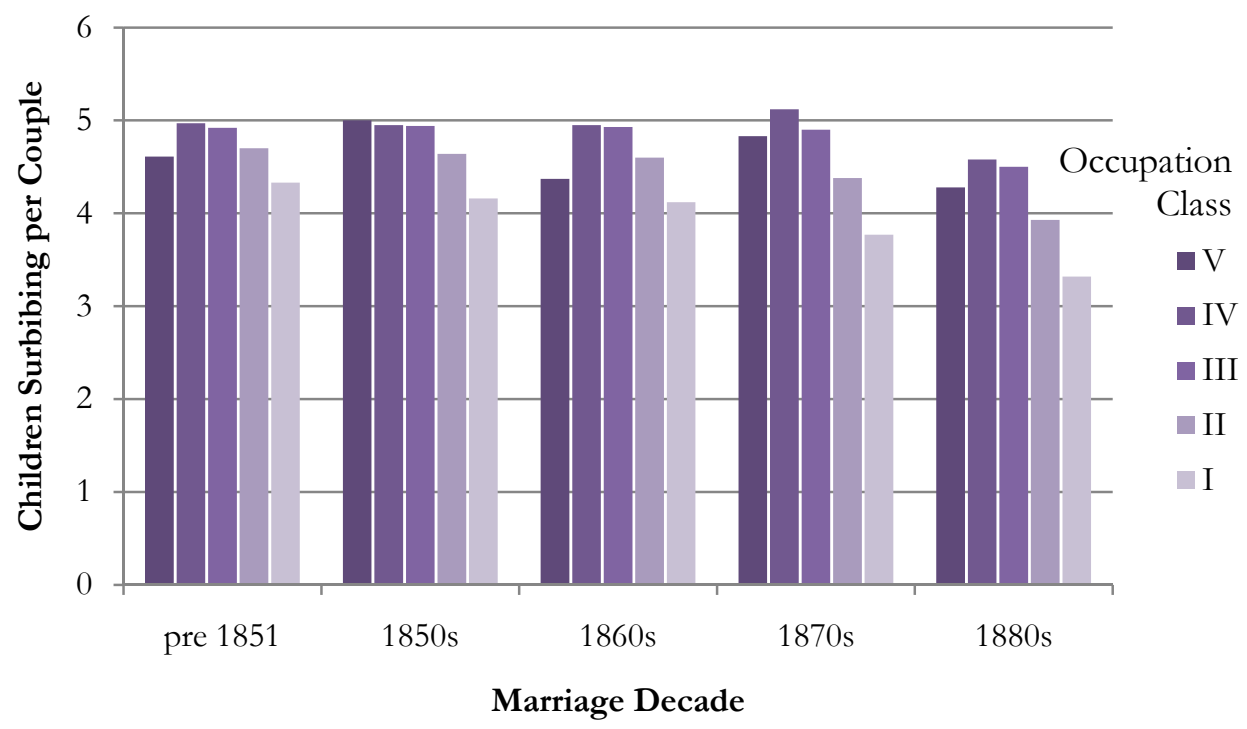

Notes: The Occupational Class scale here is that of T.H.C Stevenson. The classes I, professional and upper classes, e.g. doctors and commercial clerks, II, intermediate (e.g. farmers and shop keepers), III (skilled workmen, IV, workmen of undetermined skills (e.g. fishermen) and V, the unskilled.

Source: General Registrar's Office, 1923, Part II, p. xcvii. 
Figure 3: The Geography of the Wills Sample

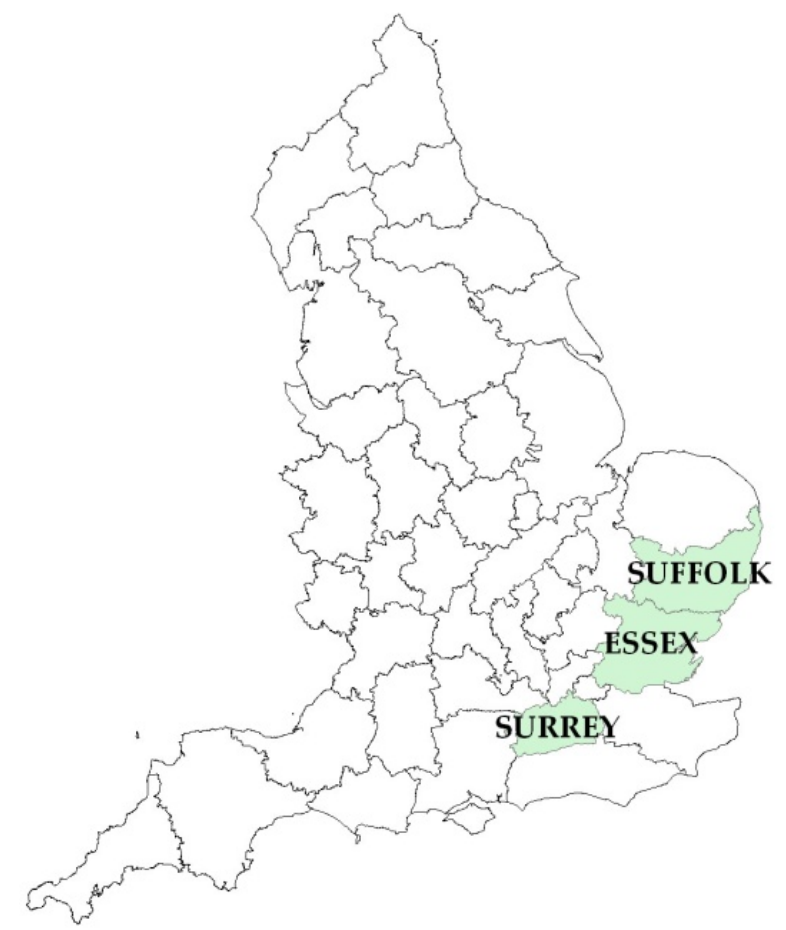

Source: Great Britain Historical GIS, 2009.

Figure 4: Proportion of Men with Surviving Wills, Suffolk 1500-1702

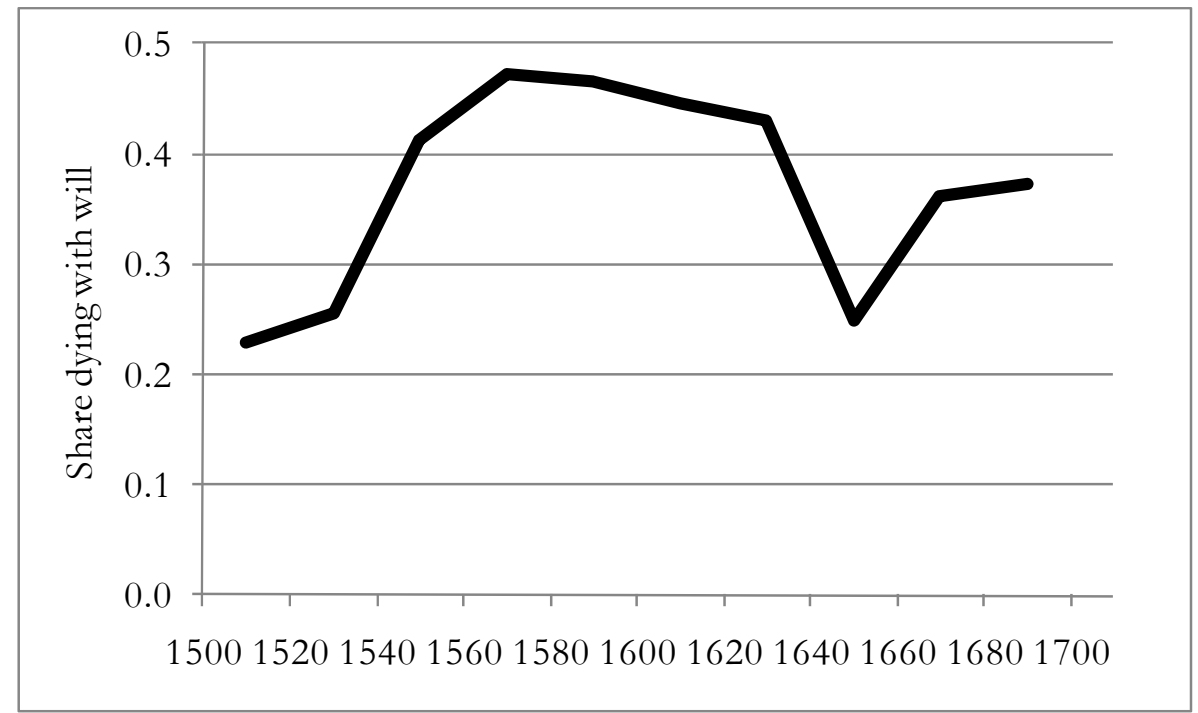

Notes: The dashed line shows the share of men with wills reporting their occupation. The smaller share 1640-59 is a result of the interregnum elimination of local ecclesiastical courts 1652-60. Source: Clark, Cummins and Smith (2010). 
Figure 5: Net marital fertility by wealth decile, pre and post 1830

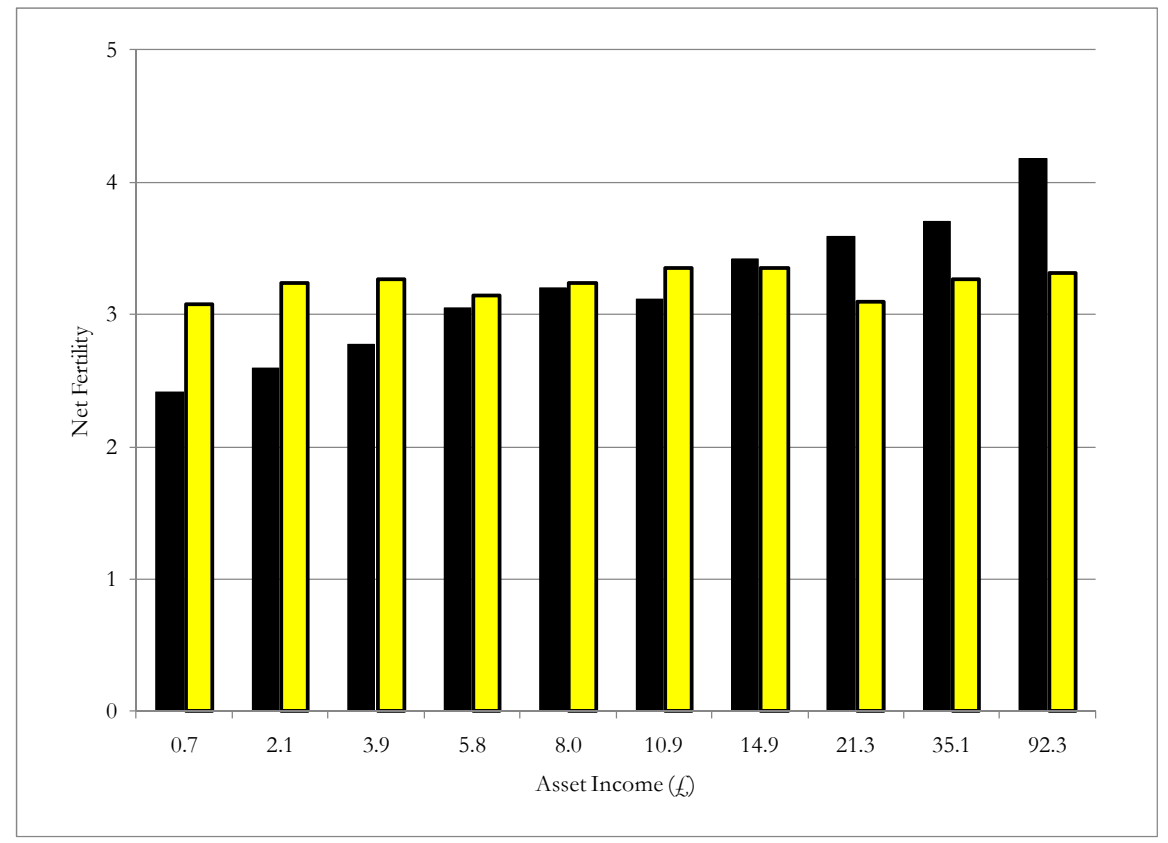

Figure 6: Wealth by Age, Probates before and after 1830

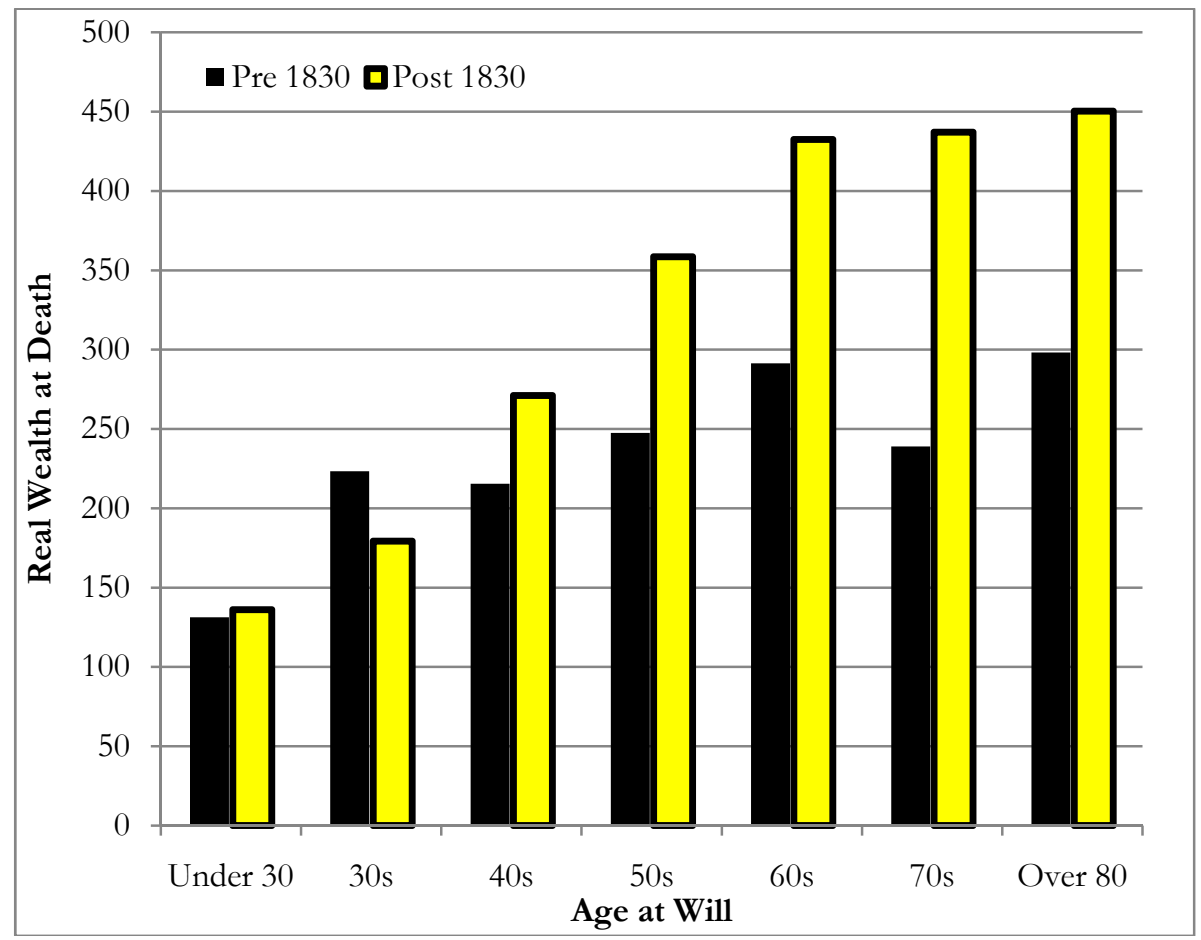


Figure 7: Net Fertility by Terciles, probate cohorts, 1500-1914

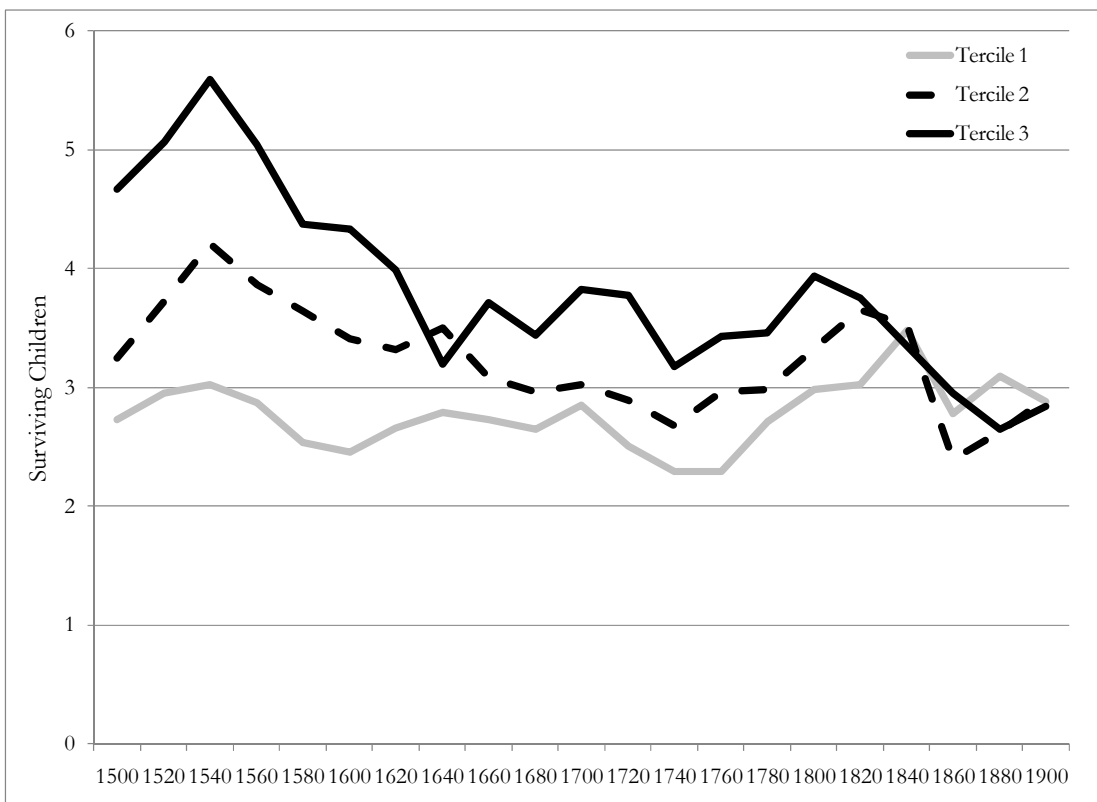

Figure 8: Net Fertility by Terciles, marriage cohorts, 1500-1879

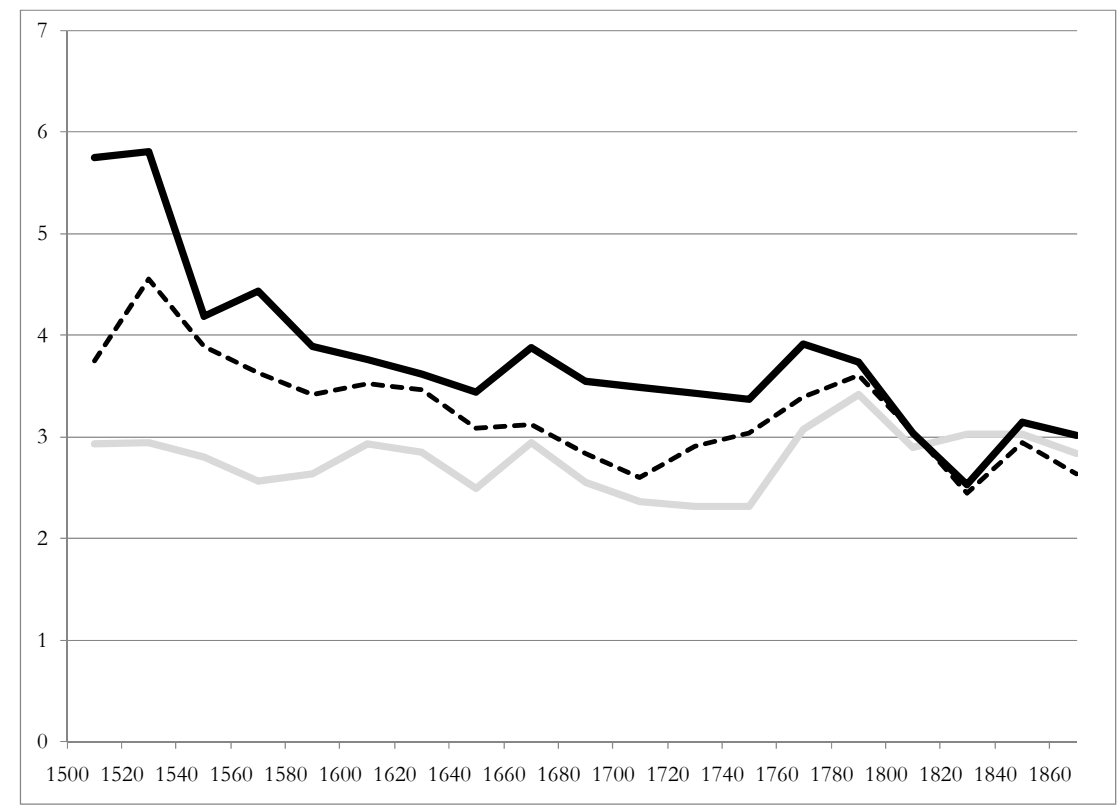


Figure 9: Net Fertility Differences, Top minus Bottom Tercile, 1500-1879

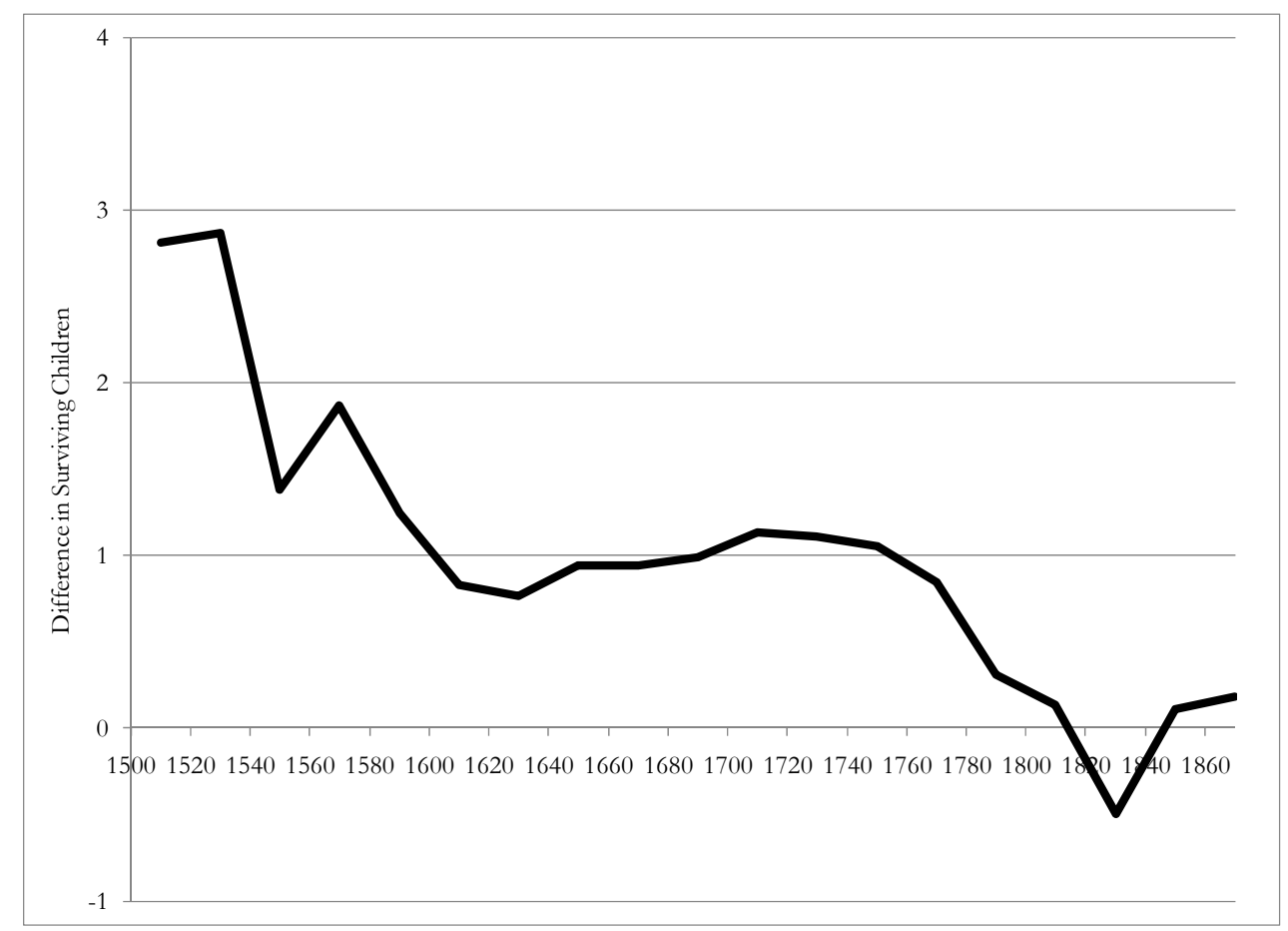

Figure 10: Fraction Never Married, by wealth decile, deaths 1500-1830 and 1830-59

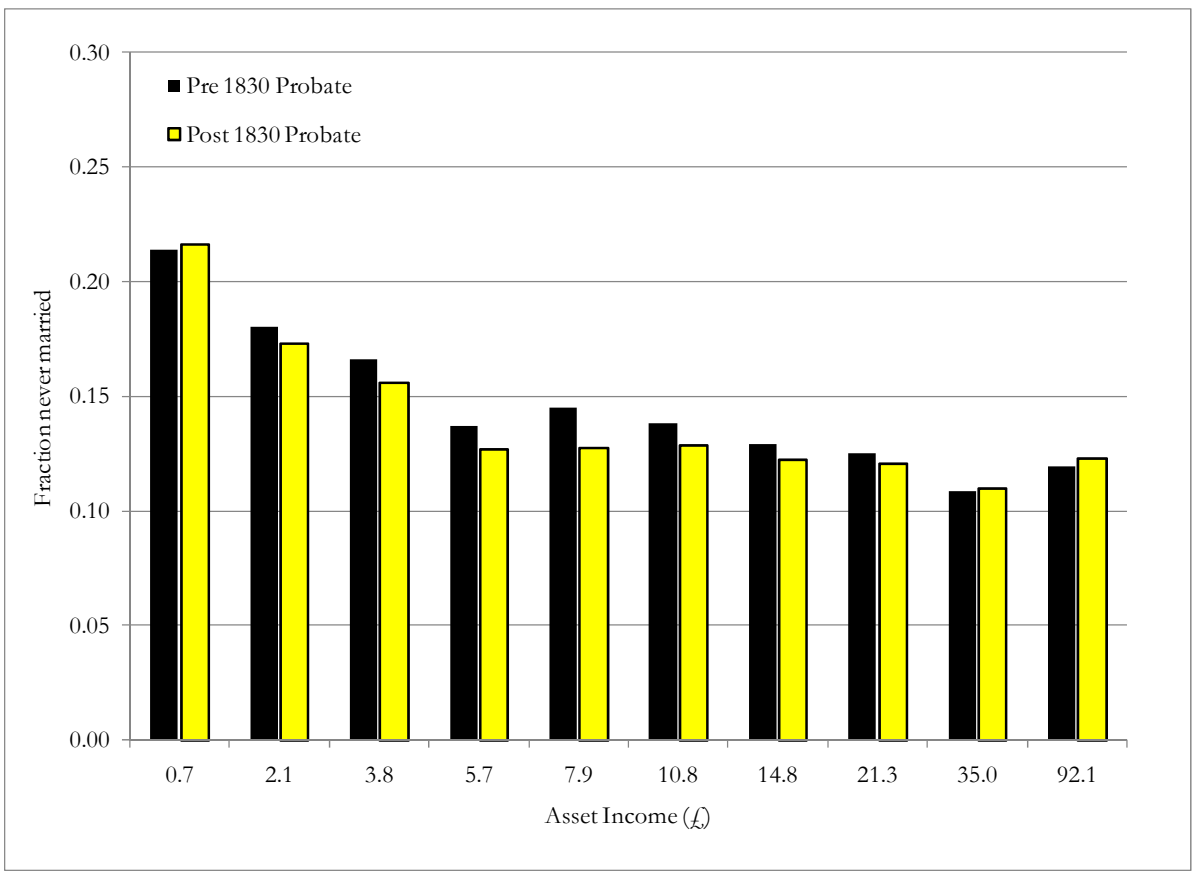


Figure 11: Share of testators in each wealth tercile, by marriage cohort

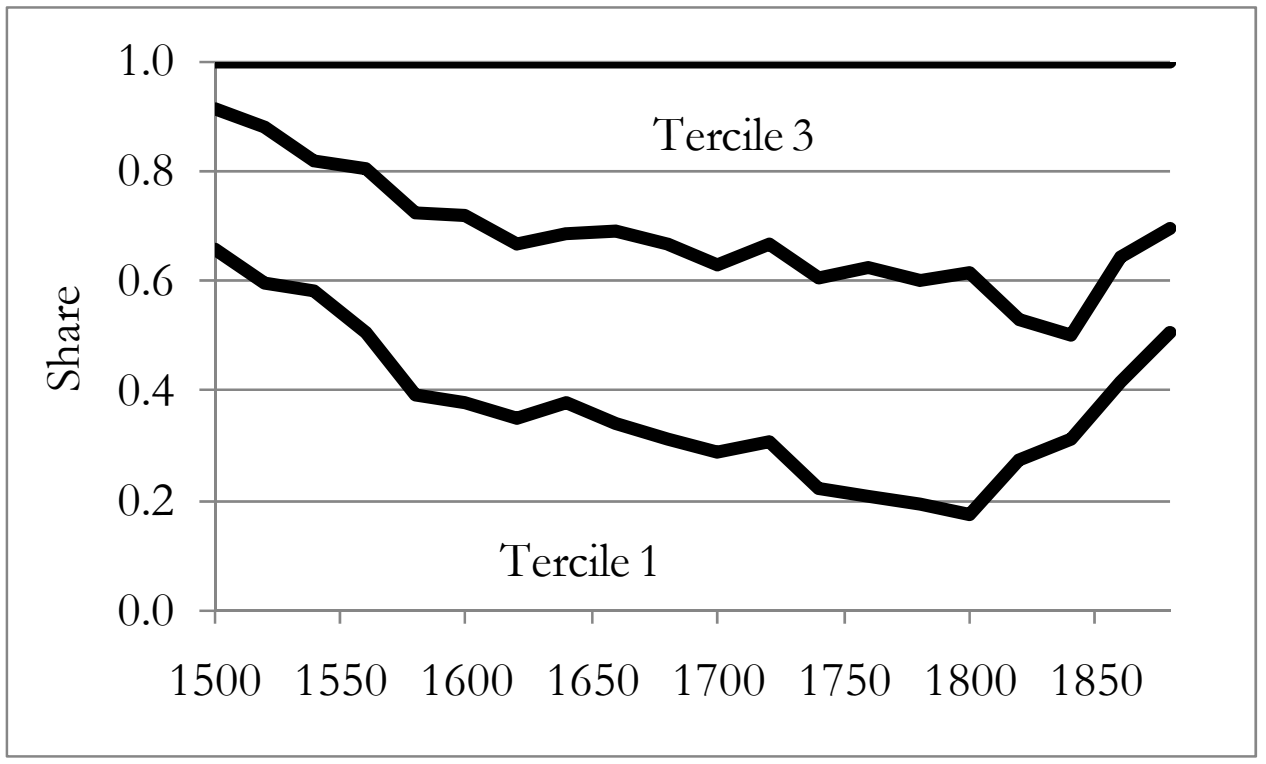

Figure 12: Absolute and Relative Wealth and Net Fertility, marriage cohorts before 1800

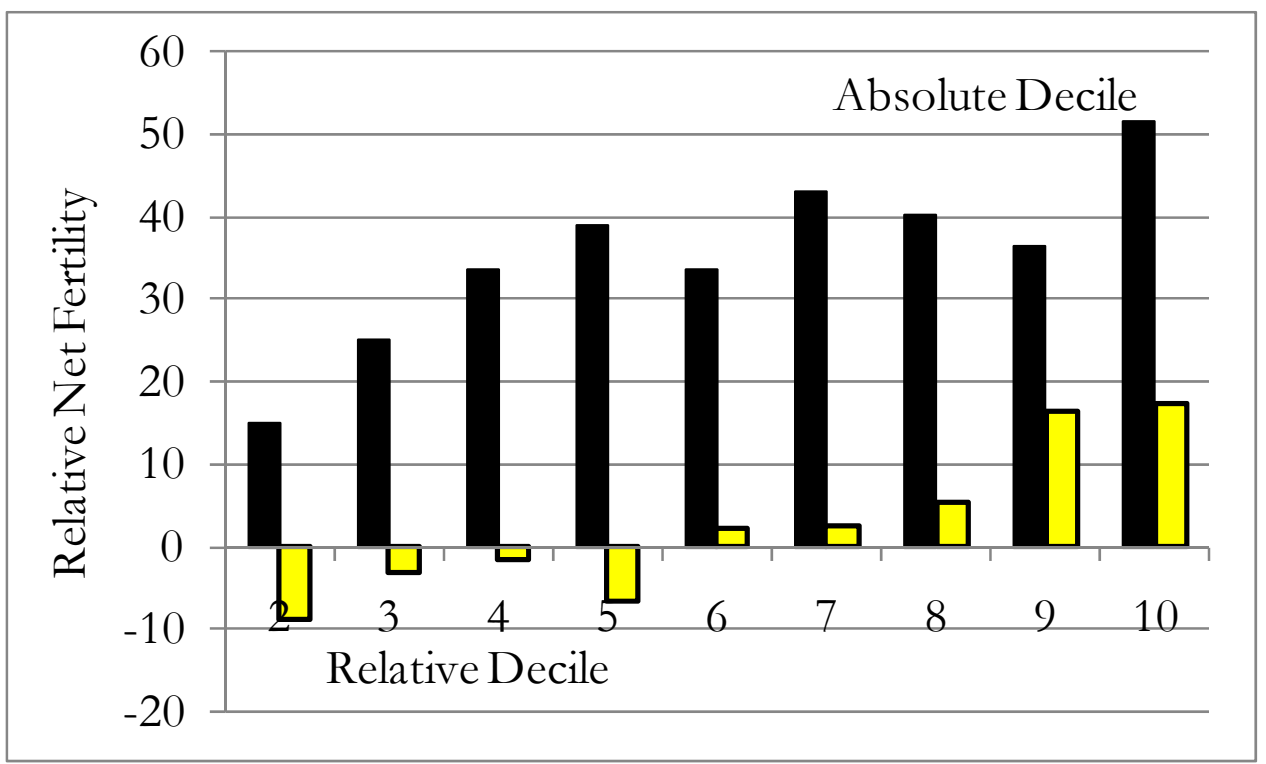


Figure 13: Chances of no surviving child by wealth decile, ever married men

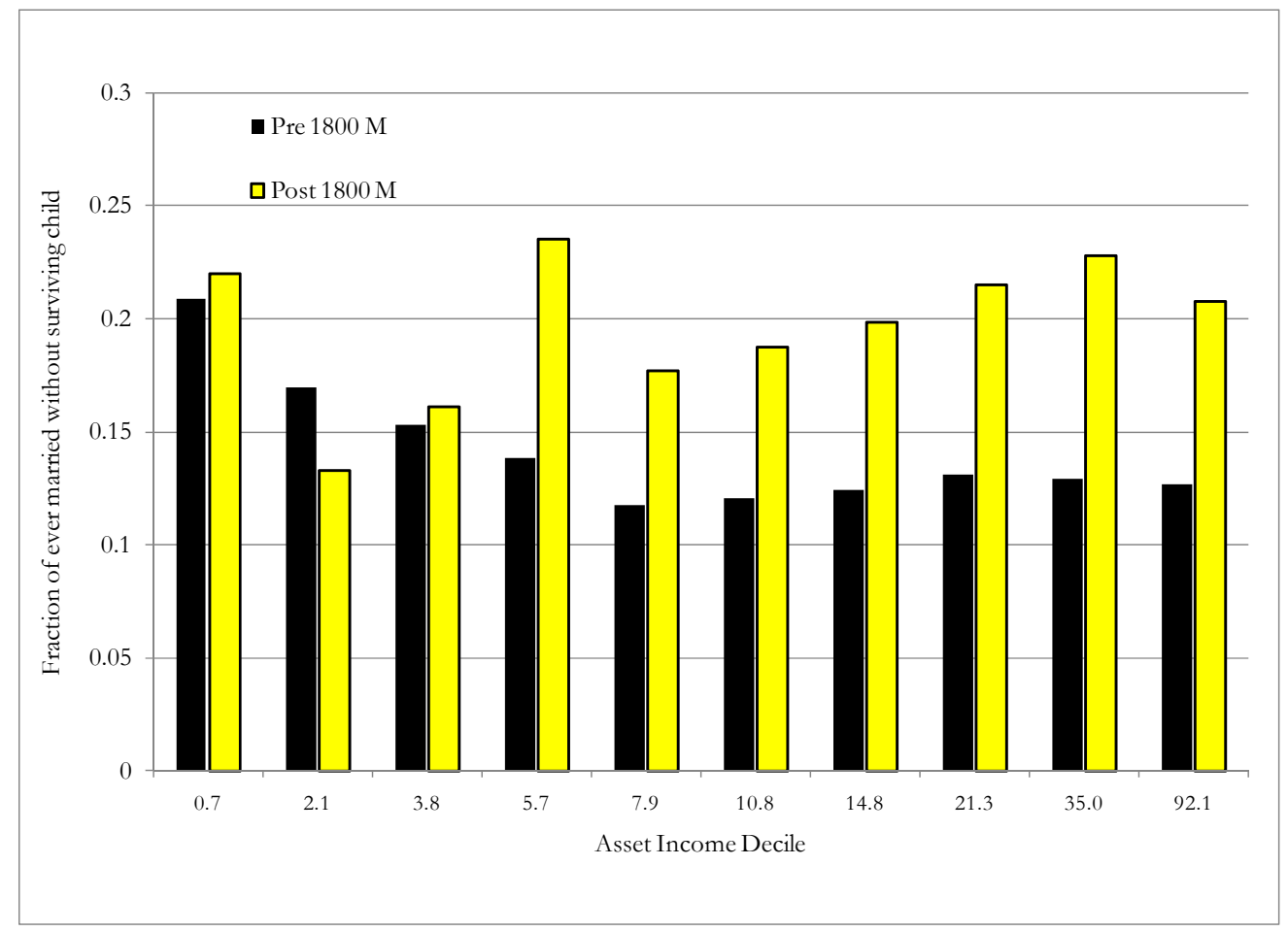


Table 1: Summary of the Wills Data

\begin{tabular}{|c|c|c|c|c|c|c|}
\hline $\begin{array}{l}\text { Period } \\
\text { (death) }\end{array}$ & $\mathrm{N}$ & $\begin{array}{l}\text { Median } \\
\text { Assets } \\
(£, 1630)\end{array}$ & $\begin{array}{l}\text { Minimum } \\
\text { Assets } \\
(£, 1630)\end{array}$ & $\begin{array}{l}\text { Maximum } \\
\text { Assets } \\
(£, 1630)\end{array}$ & $\begin{array}{l}\text { Median } \\
\text { Asset } \\
\text { Income } \\
(£, 1630)\end{array}$ & $\begin{array}{c}\text { Average } \\
\text { Age at } \\
\text { Death }\end{array}$ \\
\hline $1500-49$ & 475 & 72 & -36 & 4,873 & 3.64 & 52.0 \\
\hline 1550-99 & 1,071 & 88 & -40 & 268,313 & 4.35 & 50.5 \\
\hline $1600-49$ & 2,827 & 144 & -39 & 25,328 & 7.66 & 53.6 \\
\hline $1650-99$ & 1,295 & 175 & -41 & 14,772 & 8.85 & 56.6 \\
\hline $1700-49$ & 1,761 & 211 & -218 & 21,367 & 9.20 & 58.0 \\
\hline $1750-99$ & 2,019 & 317 & -12 & 271,258 & 12.40 & 60.0 \\
\hline $1800-49$ & 2,385 & 338 & -14 & 137,382 & 11.24 & 63.4 \\
\hline 1850-1914 & 2,404 & 426 & 0 & 203,498 & 12.27 & 65.8 \\
\hline
\end{tabular}

Note: All prices deflated to those of 1630-9.

Table 2: Social Status, Assets and Literacy, pre 1800 deaths

\begin{tabular}{lrrrr}
\hline Social group & $\mathrm{N}$ & $\begin{array}{c}\text { Average } \\
\text { assets }(£)\end{array}$ & $\begin{array}{c}\% \\
\text { literate }\end{array}$ & $\begin{array}{c}\text { Ave Age } \\
\text { at Death }\end{array}$ \\
\hline Gentry & 431 & 804 & 0.90 & 56.7 \\
Merchants/Professionals & 525 & 354 & 0.90 & 54.8 \\
Farmers & 2,661 & 304 & 0.59 & 58.5 \\
Traders & 771 & 242 & 0.69 & 55.1 \\
Craftsmen & 1,343 & 154 & 0.68 & 55.8 \\
Husbandmen & 1,711 & 83 & 0.43 & 55.4 \\
Laborers /Servants & 275 & 42 & 0.37 & 52.4 \\
& & & & \\
\hline
\end{tabular}


Table 3: Social Status, Assets and Average Age, post 1800 deaths

\begin{tabular}{|c|c|c|c|c|}
\hline Social group & $\mathrm{N}$ & $\begin{array}{c}\text { Average } \\
\text { assets } \\
(£)\end{array}$ & $\begin{array}{c}\text { Ave Age at } \\
\text { Death }\end{array}$ & $\begin{array}{c}\text { Ave Age at } \\
\text { Death }\end{array}$ \\
\hline Gentry/Independent & 462 & 1,160 & 0.90 & 67.3 \\
\hline Merchants/Professionals & 696 & 610 & 0.96 & 64.5 \\
\hline Farmers & 1,069 & 465 & 0.75 & 66.6 \\
\hline Traders & 827 & 328 & 0.89 & 61.6 \\
\hline Craftsmen & 835 & 304 & 0.88 & 64.3 \\
\hline Husbandmen & 361 & 181 & 0.69 & 65.0 \\
\hline Laborers/Servants & 250 & 150 & 0.52 & 64.8 \\
\hline
\end{tabular}


Table 4: Net Fertility of the Top versus the Bottom Tercile

\begin{tabular}{|c|c|c|c|c|}
\hline $\begin{array}{l}\text { Marriage } \\
\text { period }\end{array}$ & Observations & $\begin{array}{l}\text { Coefficient } \\
\text { Estimate }\end{array}$ & $\begin{array}{l}\text { Standard } \\
\text { Error }\end{array}$ & $\begin{array}{c}\text { Standard } \\
\text { Error }\end{array}$ \\
\hline 1500-19 & 272 & $0.554 * *$ & 0.159 & 74 \\
\hline 1520-39 & 240 & $0.749 * *$ & 0.163 & 111 \\
\hline $1540-59$ & 411 & $0.574 * *$ & 0.106 & 78 \\
\hline 1560-79 & 708 & $0.482^{* *}$ & 0.071 & 62 \\
\hline 1580-99 & 1,100 & $0.417 * *$ & 0.054 & 52 \\
\hline 1600-19 & 1,253 & $0.456^{* *}$ & 0.056 & 58 \\
\hline $1620-39$ & 597 & $0.234^{* *}$ & 0.079 & 26 \\
\hline $1640-59$ & 597 & $0.317^{* *}$ & 0.083 & 37 \\
\hline 1660-79 & 583 & $0.393^{* *}$ & 0.084 & 48 \\
\hline 1680-99 & 649 & $0.282^{* *}$ & 0.081 & 33 \\
\hline 1700-19 & 814 & $0.345^{* *}$ & 0.074 & 41 \\
\hline 1720-39 & 946 & $0.397 * *$ & 0.072 & 49 \\
\hline $1740-59$ & 778 & $0.337 * *$ & 0.082 & 40 \\
\hline $1760-79$ & 799 & 0.153 & 0.079 & 17 \\
\hline 1780-99 & 1,026 & $0.139 *$ & 0.068 & 15 \\
\hline 1800-19 & 1,067 & 0.086 & 0.075 & 9 \\
\hline 1820-39 & 745 & -0.112 & 0.083 & -11 \\
\hline 1840-59 & 785 & 0.005 & 0.080 & 1 \\
\hline 1860-79 & 457 & 0.077 & 0.117 & 8 \\
\hline 1880-99 & 85 & -0.080 & 0.322 & -8 \\
\hline
\end{tabular}

Notes: Because numbers of surviving children is a count variable the regression was estimated as a negative binomial. The estimated coefficients thus have to be exponentiated to get the fertility levels by asset class. $* *=$ statistically significant at the $1 \%$ level, $*=$ statistically significant at the $5 \%$ level 
Table 5: Wealth, Status and Literacy as competing fertility determinants

\begin{tabular}{|c|c|c|c|c|}
\hline & $\begin{array}{l}\text { Marriages } \\
1500-1799\end{array}$ & & $\begin{array}{l}\text { Marriages } \\
1800-1914\end{array}$ & \\
\hline & Coefficient & $\begin{array}{l}\text { Standard } \\
\text { Error }\end{array}$ & Coefficient & $\begin{array}{l}\text { Standard } \\
\text { Error }\end{array}$ \\
\hline Wealth Decile 1 & 0.000 & - & 0.000 & - \\
\hline Wealth Decile 2 & 0.089 & 0.040 & 0.081 & 0.101 \\
\hline Wealth Decile 3 & 0.167 & 0.039 & -0.059 & 0.108 \\
\hline Wealth Decile 4 & 0.255 & 0.040 & -0.022 & 0.100 \\
\hline Wealth Decile 5 & 0.312 & 0.040 & -0.051 & 0.103 \\
\hline Wealth Decile 6 & 0.302 & 0.040 & -0.030 & 0.102 \\
\hline Wealth Decile 7 & 0.388 & 0.040 & 0.010 & 0.100 \\
\hline Wealth Decile 8 & 0.422 & 0.041 & 0.008 & 0.099 \\
\hline Wealth Decile 9 & 0.471 & 0.041 & -0.015 & 0.095 \\
\hline Wealth Decile 10 & 0.603 & 0.043 & 0.106 & 0.089 \\
\hline Laborers, Servants & -0.013 & 0.053 & 0.127 & 0.132 \\
\hline Husbandmen & 0.053 & 0.029 & 0.285 & 0.123 \\
\hline Craftsmen & 0.093 & 0.031 & 0.237 & 0.108 \\
\hline Traders & 0.014 & 0.036 & 0.181 & 0.108 \\
\hline Yeomen, farmers & 0.092 & 0.027 & 0.206 & 0.109 \\
\hline Merchants, professionals & -0.012 & 0.042 & 0.164 & 0.110 \\
\hline Gentlemen & -0.071 & 0.043 & 0.026 & 0.118 \\
\hline Literate & -0.013 & 0.020 & 0.089 & 0.067 \\
\hline Farm residence & 0.085 & 0.021 & 0.067 & 0.077 \\
\hline Town residence & -0.068 & 0.020 & -0.084 & 0.043 \\
\hline London residence & -0.409 & 0.035 & -0.149 & 0.121 \\
\hline $\mathrm{N}$ & 8,972 & & 2,033 & \\
\hline
\end{tabular}

Note: For occupation/social status the missing category are those without a reported occupation or status. 
Table A1: Numbers of sons and daughters in wills, and inflation factors used before 1580

\begin{tabular}{|c|c|c|c|c|c|}
\hline Place & $\begin{array}{c}\text { Probate } \\
\text { Period }\end{array}$ & $\mathrm{n}$ & $\begin{array}{c}\text { Average } \\
\text { boys }\end{array}$ & $\begin{array}{c}\text { Average } \\
\text { girls }\end{array}$ & $\begin{array}{c}\text { Inflation } \\
\text { factor for } \\
\text { girls }\end{array}$ \\
\hline Countryside & $1500-49$ & 289 & 1.77 & 1.27 & 1.33 \\
\hline Countryside & $1550-79$ & 387 & 1.61 & 1.33 & 1.16 \\
\hline Countryside & 1580-99 & 419 & 1.60 & 1.50 & 1 \\
\hline Countryside & $1600-99$ & 3,317 & 1.41 & 1.35 & 1 \\
\hline Countryside & 1700-99 & 2,110 & 1.24 & 1.14 & 1 \\
\hline Countryside & $1800-58$ & 1,496 & 1.43 & 1.36 & 1 \\
\hline Town & $1500-49$ & 115 & 1.47 & 0.96 & 1.53 \\
\hline Town & 1550-79 & 63 & 1.24 & 1.32 & 1 \\
\hline Town & 1580-99 & 108 & 0.90 & 0.96 & 1 \\
\hline Town & 1600-99 & 749 & 1.32 & 1.32 & 1 \\
\hline Town & 1700-99 & 968 & 1.13 & 1.09 & 1 \\
\hline Town & $1800-58$ & 645 & 1.30 & 1.16 & 1 \\
\hline London & $1500-49$ & 98 & .55 & .55 & 1 \\
\hline London & 1550-79 & 61 & .62 & .74 & 1 \\
\hline London & 1580-99 & 37 & .49 & .32 & 1 \\
\hline London & $1600-99$ & 625 & .69 & .79 & 1 \\
\hline London & 1700-99 & 647 & .62 & .70 & 1 \\
\hline London & 1800-58 & 164 & .91 & .95 & 1 \\
\hline
\end{tabular}


Table A2: Average numbers of children for families meeting the condition "children $\geq$ n"

\begin{tabular}{llllllllll}
\hline Place & Period & $\mathbf{2} \mathbf{1}$ & $\mathbf{2}$ & $\mathbf{2} \mathbf{3}$ & $\mathbf{2} \mathbf{4}$ & $\mathbf{2} \mathbf{5}$ & $\mathbf{2} \mathbf{6}$ & $\mathbf{2} \mathbf{7}$ & $\mathbf{\geq} 8$ \\
& & & & & & & & & \\
\hline Countryside & $1580-1799$ & 3.63 & 4.10 & 4.76 & 5.47 & 6.20 & 7.08 & 7.90 & 8.81 \\
Countryside & $1800-59$ & 4.01 & 4.52 & 5.22 & 5.92 & 6.73 & 7.44 & 8.24 & 9.10 \\
Countryside & Post 1859 & 3.50 & 4.26 & 5.03 & 5.85 & 6.49 & 7.35 & 7.86 & 9.00 \\
& & & & & & & & & \\
Town & $1580-1799$ & 3.41 & 3.97 & 4.70 & 5.40 & 6.22 & 6.98 & 7.88 & 8.88 \\
Town & $1800-59$ & 3.79 & 4.44 & 5.04 & 5.76 & 6.45 & 7.22 & 8.09 & 9.35 \\
Town & Post 1859 & 3.32 & 3.90 & 4.69 & 5.41 & 6.21 & 6.95 & 7.82 & 9.00 \\
& & & & & & & & & \\
London & $1580-1799$ & 2.48 & 3.27 & 4.28 & 5.14 & 6.06 & 6.86 & 7.57 & 8.14 \\
London & $1800-59$ & 3.06 & 3.79 & 4.39 & 4.98 & 6.17 & 6.50 & 7.75 & - \\
London & Post 1859 & 3.25 & 4.00 & 5.00 & - & - & - & - & - \\
& & & & & & & & & \\
\hline
\end{tabular}

Table A.3: Birth Information

\begin{tabular}{lcc}
\hline \multicolumn{1}{c}{ Group } & $\mathrm{N}$ & Birth date also \\
& & $\mathrm{N}$ \\
\hline & & \\
Birth date & 1,112 & - \\
Marriage date & 1,132 & 451 \\
Age at first child & 1,223 & 506 \\
At least one of above & 2,138 & - \\
& & \\
\hline
\end{tabular}


Table A.4: Average 'Testators' and Wives' Ages at First Marriage

\begin{tabular}{lcccccc}
\hline $\begin{array}{l}\text { Period of } \\
\text { marriage }\end{array}$ & $\mathrm{N}$ & $\begin{array}{c}\text { Average age } \\
\text { at marriage } \\
\text { (testators) }\end{array}$ & $\begin{array}{c}\text { WDOS } \\
\text { (bachelor } \\
\text { / spinster } \\
\text { marriages) }\end{array}$ & $\mathrm{N}$ & $\begin{array}{c}\text { Average age } \\
\text { at marriage } \\
\text { (wives) }\end{array}$ & $\begin{array}{c}\text { WDOS } \\
\text { (bache- } \\
\text { lor/spinster } \\
\text { marriages) }\end{array}$ \\
\hline & & & & & \\
$1500-99$ & 263 & 27.5 & - & 80 & 24.1 & - \\
$1600-99$ & 100 & 28.0 & 27.5 & 73 & 23.2 & 25.7 \\
$1700-99$ & 246 & 27.5 & 26.4 & 190 & 24.2 & 23.0 \\
$1800-37$ & 135 & 28.4 & 25.1 & 88 & 24.5 & - \\
$1838-1914$ & 94 & 28.2 & - & 78 & 23.7 & \\
& & & & & & \\
\hline
\end{tabular}

Sources: Wrigley et al., 1997, table 5.7, p. 149 (WDOS). International Genealogical Index. 
Table A5: Estimating Land Areas

\begin{tabular}{|c|c|c|}
\hline Variable & $\begin{array}{c}\text { Estimated values } \\
\text { Cash }\end{array}$ & Standard Errors \\
\hline Constant & 1.198 & .144 \\
\hline D1700 & -.095 & .088 \\
\hline D1800 & $-.370 * *$ & .117 \\
\hline DPCC & $-.283^{*}$ & .141 \\
\hline SQRTHOUSE & $.252 * *$ & .052 \\
\hline LPAR & $1.18^{* *}$ & .105 \\
\hline SQRTPROBATE & $.0104 * *$ & .002 \\
\hline SQRTCASHGDS & $.0295^{* *}$ & .004 \\
\hline DLIT & $.277 * *$ & .090 \\
\hline DLITUNKNOWN & $.219 *$ & .108 \\
\hline DTOWN & $-0.280 * *$ & .097 \\
\hline DFARM & $.258^{* *}$ & .088 \\
\hline Laborer & $-1.241 * *$ & .274 \\
\hline Husbandman & $-.544 * *$ & .159 \\
\hline Craftsman & $-.508^{* *}$ & .165 \\
\hline Tradesman & -.169 & .184 \\
\hline Yeoman/Farmer & $.412 * *$ & .138 \\
\hline Merchant/Professional & -.212 & .207 \\
\hline Gentleman & $.548^{*}$ & .193 \\
\hline $\mathrm{R}^{2}$ & 0.38 & \\
\hline $\mathrm{N}$ & 1,261 & \\
\hline
\end{tabular}

Notes: $* *=$ statistically significant at the $1 \%$ level, $*=$ statistically significant at the $5 \%$ level. 
Table A.6: Estimating Real Probate Values

Variable

\section{Estimated coeffi- Standard Errors \\ cient values}

\begin{tabular}{lcc}
\hline & & \\
Constant & 9.15 & 6.93 \\
DPCC & $233.2^{* *}$ & 5.80 \\
DNONCUP & 14.07 & 18.13 \\
d1500-99 & -6.63 & 16.27 \\
d1700-99 & $21.87^{*}$ & 9.29 \\
d1800-59 & -4.34 & 10.06 \\
d1860-1914 & $310.3^{* *}$ & 20.35 \\
CASHGDS & $1.096^{* *}$ & 0.001 \\
Real Estate & $0.046^{* *}$ & 0.002 \\
DDUTY & $26.94 * *$ & 9.10 \\
DLIT & 2.72 & 4.20 \\
DLITUNKNOWN & 3.36 & 5.17 \\
DLON & $-46.63^{* *}$ & 6.70 \\
DTOWN & 5.10 & 4.13 \\
DFARM & 9.15 & 4.93 \\
Laborer & -11.4 & 10.13 \\
Husbandman & -4.6 & 7.35 \\
Craftsman & 7.0 & 6.94 \\
Tradesman & $52.5^{* *}$ & 7.47 \\
Yeoman/Farmer & 11.8 & 6.92 \\
Merchant/Professional & $93.3 * *$ \\
Gentleman & $97.3^{* *}$ & \\
R 2.33 \\
N & & \\
\hline
\end{tabular}

Notes: $* *=$ statistically significant at the $1 \%$ level, $*=$ statistically significant at the $5 \%$ level. 


\section{Table A.7: Estimated likelihood of absence of real estate}

\begin{tabular}{|c|c|c|}
\hline Variable & $\begin{array}{l}\text { Estimated coeffi- } \\
\text { cient values }\end{array}$ & Standard Errors \\
\hline Constant & 0.380 & 0.157 \\
\hline DPCC & -.26249 & .1359 \\
\hline DNONCUP & $1.6070 * *$ & .5743 \\
\hline $1500-99$ & -.7515834 & .4090 \\
\hline $1700-59$ & -.2666 & 1991 \\
\hline $1760-1859$ & $-.8264 * *$ & .1550 \\
\hline $1860-1915$ & $.7801 * *$ & .1355 \\
\hline SQRT(probate or duty value) & $-.00625^{* *}$ & .00163 \\
\hline DDUTY & $.4341 * *$ & .1169 \\
\hline Literate & -.2459 & .0945 \\
\hline Unknown Literacy & .1887 & .1125 \\
\hline Town dweller & .0575 & .0819 \\
\hline London dweller & $1.0378^{* *}$ & .1435 \\
\hline Farm dweller & .1880 & .1116 \\
\hline Laborer & $-.4339 *$ & .1979 \\
\hline Husbandman & $-.6218^{* *}$ & .1608 \\
\hline Craftsman & $-.9704 * *$ & .1507 \\
\hline Tradesman & $-.7797 * *$ & .1546 \\
\hline Yeoman/Farmer & $-.8950 * *$ & .1555 \\
\hline Merchant/Professional & $-.4905^{* *}$ & .1664 \\
\hline Gentleman & $-1.0216^{* *}$ & .1772 \\
\hline Pseudo $\mathrm{R}^{2}$ & 0.08 & \\
\hline $\mathrm{N}$ & 4,353 & \\
\hline
\end{tabular}

Notes: $* *=$ statistically significant at the $1 \%$ level, $*=$ statistically significant at the $5 \%$ level. 
Table A.8: Estimating Real Estate Value

\begin{tabular}{|c|c|c|}
\hline Variable & $\begin{array}{l}\text { Estimated coeffi- } \\
\text { cient values }\end{array}$ & Standard Errors \\
\hline Constant & 4.23 & 0.10 \\
\hline DPCC & 0.040 & 0.066 \\
\hline 1500-99 & $-.7155^{* *}$ & .219 \\
\hline $1700-59$ & $.3318 * *$ & .123 \\
\hline $1760-1859$ & $.5060 * *$ & .098 \\
\hline $1860-1914$ & $1.424 * *$ & .0824 \\
\hline SQRT(PROBATE) & $0.0051^{* *}$ & 0.0008 \\
\hline DDUTY & -0.045 & 0.079 \\
\hline DLON & $0.698 * *$ & 0.093 \\
\hline DTOWN & $0.295^{* *}$ & 0.045 \\
\hline DFARM & 0.004 & 0.060 \\
\hline Literate & $0.182^{* *}$ & 0.052 \\
\hline Unknown Literacy & $0.330^{* *}$ & 0.063 \\
\hline Laborer & -0.109 & 0.124 \\
\hline Husbandman & -0.129 & 0.101 \\
\hline Craftsman & 0.145 & 0.093 \\
\hline Tradesman & 0.093 & 0.097 \\
\hline Yeoman/Farmer & 0.257 & 0.095 \\
\hline Merchant/Professional & 0.119 & 0.106 \\
\hline Gentleman & $0.486^{* *}$ & 0.103 \\
\hline $\mathrm{R}^{2}$ & 0.31 & \\
\hline $\mathrm{N}$ & 2,636 & \\
\hline
\end{tabular}

Notes: $* *=$ statistically significant at the $1 \%$ level, $*=$ statistically significant at the $5 \%$ level. 
Table A.9: The Range of Wealth Data Types in the Wills by period

\begin{tabular}{lcccccc}
\hline $\begin{array}{c}\text { Asset } \\
\text { Quality }\end{array}$ & $\begin{array}{c}\text { Probate, real } \\
\text { estate, land } \\
\text { area }\end{array}$ & $\begin{array}{c}\text { Cash, real } \\
\text { estate, } \\
\text { land area }\end{array}$ & $\begin{array}{c}\text { Probate, } \\
\text { real estate } \\
\text { land area } \\
\text { unknown }\end{array}$ & $\begin{array}{c}\text { Cash, real } \\
\text { estate } \\
\text { land area } \\
\text { unknown }\end{array}$ & $\begin{array}{c}\text { Probate } \\
\text { real estate } \\
\text { unknown }\end{array}$ & All \\
\hline \multirow{10}{1500-99}{} & 16 & 883 & 10 & 459 & 2 & 1,629 \\
$1600-99$ & 486 & 1,953 & 142 & 1,185 & 103 & 4,230 \\
$1700-99$ & 486 & 2,010 & 144 & 656 & 345 & 4,253 \\
$1800-59$ & 1,439 & 249 & 311 & 100 & 635 & 2,782 \\
post 1860 & 1,093 & 5 & 51 & 6 & 614 & 1,771 \\
Total & 3,520 & 5,100 & 658 & 2,406 & 1,699 & 14,665 \\
& & & & & & \\
\hline
\end{tabular}

Table A.10: Share of Real Estate and Farmland in Assets

\begin{tabular}{cccc}
$\begin{array}{c}\text { Asset } \\
\text { Quality }\end{array}$ & $\begin{array}{c}\text { Average share } \\
\text { of Real Estate } \\
\text { values in } \\
\text { bequest totals } \\
\text { (all wills) }\end{array}$ & $\begin{array}{c}\text { Bequests with } \\
\text { real estate as a } \\
\text { share of all } \\
\text { bequest } \\
\text { (all wills) }\end{array}$ & $\begin{array}{c}\text { Average } \\
\text { share of } \\
\text { Farmland } \\
\text { in bequests } \\
\text { (wills with } \\
\text { land) }\end{array}$ \\
\hline 1500-99 & 0.12 & 0.30 & 0.29 \\
$1600-99$ & 0.25 & 0.43 & 0.33 \\
$1700-99$ & 0.35 & 0.36 & 0.31 \\
$1800-59$ & 0.36 & 0.34 & 0.28 \\
post 1860 & 0.21 & 0.22 & 0.27 \\
& & & \\
\hline
\end{tabular}


Table A.11: Median Wealth by Asset Quality

\begin{tabular}{lccccc}
\hline Asset Quality & $\begin{array}{c}\text { Probate, real } \\
\text { estate, land } \\
\text { area }\end{array}$ & $\begin{array}{c}\text { Cash, } \\
\text { real } \\
\text { estate, } \\
\text { land area }\end{array}$ & $\begin{array}{c}\text { Probate, } \\
\text { real estate, } \\
\text { land area } \\
\text { unknown }\end{array}$ & $\begin{array}{c}\text { Cash, real } \\
\text { estate, land } \\
\text { area } \\
\text { unknown }\end{array}$ & $\begin{array}{c}\text { Probate, real } \\
\text { estate un- } \\
\text { known }\end{array}$ \\
\hline Gentry & & & & & \\
Merchants/ & 957 & 797 & 1272 & 1056 & 683 \\
Professionals & 676 & 318 & 1217 & 577 & 277 \\
Farmers & 343 & 207 & 469 & 396 & 443 \\
Traders & 307 & 238 & 477 & 338 & 259 \\
Craftsmen & 232 & 124 & 358 & 215 & 319 \\
Husbandmen & 127 & 64 & 194 & 139 & 120 \\
Laborers/Servants & 110 & 34 & 184 & 67 & 176 \\
& & & & & \\
\hline
\end{tabular}

